\begin{tabular}{|c|c|c|c|c|c|c|}
\hline \multirow{4}{*}{ Impact Factor: } & ISRA (India) & $=3.117$ & SIS (USA) & $=0.912$ & ICV (Poland) & $=6.630$ \\
\hline & ISI (Dubai, UAE & $=0.829$ & РИНЦ (Russia & $=0.156$ & PIF (India) & $=1.940$ \\
\hline & GIF (Australia) & $=0.564$ & ESJI (KZ) & $=8.716$ & IBI (India) & $=4.260$ \\
\hline & JIF & $=1.500$ & SJIF (Morocco & $=5.667$ & OAJI (USA) & $=0.350$ \\
\hline
\end{tabular}

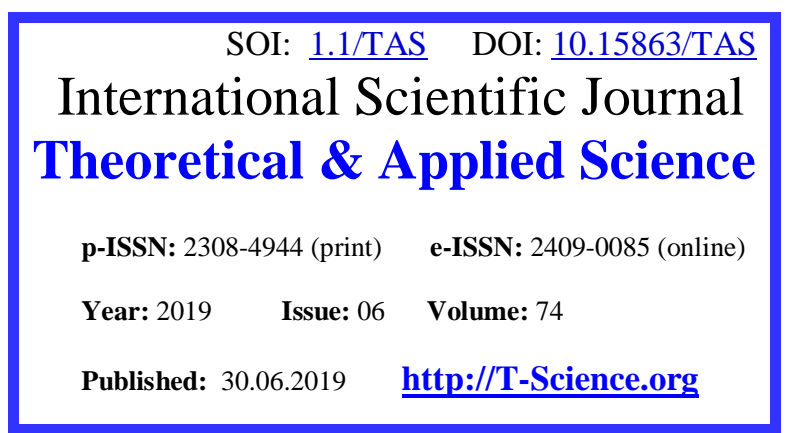

SECTION 31. Economic research, finance, innovation, risk management.

UDC 685.34: 519.73
QR - Issue

QR - Article
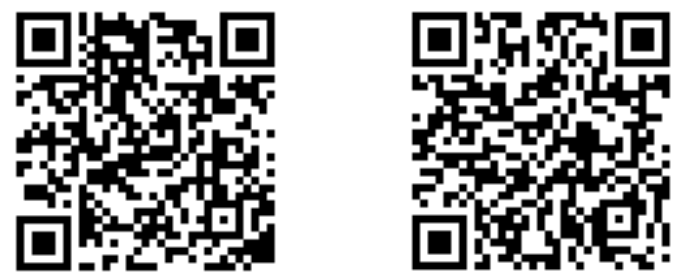

Artur Alexandrovich Blagorodov Institute of Entrepreneurship and Service sector (branch)

DSTU

bachelor, g. Shakhty

blaghorodov@list.ru

Dmitri Olegovich Bordukh

Institute of Entrepreneurship and Service sector (branch)

DSTU

bachelor, g. Shakhty

bordukh95@bk.ru

Angelina Vladimirovna Kopylova Institute of Entrepreneurship and Service sector (branch)

DSTU

bachelor, g. Shakhty angelinakopylova22121999@mail.ru

Vladimir Timofeevich Prokhorov ISOP (f) DGTU

Doctor of technical sciences, professor, professor of the department "Designing, technology and design", Shakhty prohorov@sssu.ru

Igor Mikhailovich Maltsev Institute of Entrepreneurship and Sevice sector (branch) DSTU associate Professor, Ph. D.-m H., g. Shakhty

Natalia Vassilievna Tikhonova Kazan national research technological University Doctor of technical sciences, professor Kazan, Republic of Tatarstan

\title{
SEARCH OF REASONABLE PRODUCTION OF DEMANDED PRODUCTION TO CONSUMERS OF REGIONS OF SOUTHERN FEDERAL DISTRICT AND SKFO BY RESULTS OF SOCIOLOGICAL RESEARCHES OF THE POPULATION OF THESE REGIONS
}

Abstract: The authors ventured to formulate the concept of the impact of the status "of the goods on the attractiveness of its competitiveness and relevance", to ensure import substitution domestic producer in the markets. To justify such expectations authors attracted highly skilled professionals and senior students as experts, inviting them to express their views in completing the questionnaires. The survey results were processed using the software developed by the authors, which confirmed our assumptions about the importance of the concept of the attractiveness of the goods on the status of its competitiveness and relevance. Thus, understanding the status of the appeal of the product and population, primarily the domestic consumer products. 


\begin{tabular}{|c|c|c|c|c|c|c|}
\hline \multirow{4}{*}{ Impact Factor: } & ISRA (India) & $=3.117$ & SIS (USA) & $=0.912$ & ICV (Poland) & $=6.630$ \\
\hline & ISI (Dubai, UAE & $=0.829$ & РИНЦ (Russia & $=0.156$ & PIF (India) & $=1.940$ \\
\hline & GIF (Australia) & $=0.564$ & ESJI (KZ) & $=8.716$ & IBI (India) & $=4.260$ \\
\hline & JIF & $=1.500$ & SJIF (Morocco & $=\mathbf{5 . 6 6 7}$ & OAJI (USA) & $=0.350$ \\
\hline
\end{tabular}

Key words: appeal of the goods, demand, sale, demand, competitiveness, product reliability, affordability, buying satisfaction, the credibility of the domestic manufacturer, product brand, service support of the purchased goods.

Language: English

Citation: Blagorodov, A. A., Bordukh, D. O., Kopylova, A. V., Prokhorov, V. T., Maltsev, I. M., \& Tikhonova, N. V. (2019). Search of reasonable production of demanded production to consumers of regions of southern Federal district and skfo by results of sociological researches of the population of these regions. ISJ Theoretical \& Applied Science, 06 (74), 794-822.

Soi: http://s-o-i.org/1.1/TAS-06-74-89 Doi: crossef https://dx.doi.org/10.15863/TAS.2019.06.74.89

\section{Introduction}

Consumers in the market does not appear monolithic community. When buying shoes, they are guided, first of all type of footwear and price.

For example, when choosing a buyer of women's boots into account the seasonality of the shoe, its age features and type of work, it is important attributes will then be the appearance of the shoe: matching fashion trends, colors, materials, top and bottom, as well as a constructive solution models. Buyers also prefer brand. It is an offer of shoes to the consumer in specialty stores or departments will provoke an increase in sales in an uncertain demand. And if we seller, having a well thought-out principles of presenting advantageous properties of each design women's boots, and guessing the mood and the possibility of women customers at their reasoned matters when choosing a model will be able to realize this same desire, in any case, the buyer will leave satisfied that his interests are fully satisfied and he himself,

The elderly love comfort and coziness. Both the seller and the buyer - the representative of the beautiful half - of course, turn their attention to the model, if it is nice to be worn in the snowy winter, since it must be made of soft nap leather - suede and have a molded sole with large tread, as will very comfortable and provide them comfort at any time of thYe with grave socks .. At the same time it must be affordable.

Business woman, aged 45 and 45 and residing in the vanity, of course, will give preference to models made of natural materials, low-heeled, low-key accessories, creating imposed the comfort in their daily lives, while emphasizing their image and social status.

The appearance in the cabin or in a regular store or a high school student fashionistas immediately attract the attention of interior seller who wants to offer them only the original model on the high heels especially with overhead straps, decorated holnitenami and secured at the top and bottom of the shaft. Fashionista will be pleased that bought what she wanted, and high school will be satisfied buying more because she was sure that this purchase will surprise her friends and for her - this is the most important argument in favor of buying.

Main part.
Seller always easy if there was a "socialite" in the store, as it always favors only innovations or exclusive models. These its ambitions can be met as a model at the expense of originality, and at the expense of constructive solutions, also due to the selected materials and decorations in the production of this model itself.

Girls who love the strictness, but at the same time, the originality, the seller is required to propose a model in which combines two materials of colors and textures and details, perforated, draped in the ankle, give it unusual.

And the price should not be very "bite", which is also not a few important argument in favor of buying. These are our fancy, peeped into the life and work very effectively to the demand justified and have a right to be, because the ability to present their products to work with the consumer competent marketing approach form the popularity of the boutique, shop or salon with customers and provide them with strong consumer demand . Ultimately designed principles of presenting the properties of the product, the choice of the consumer, the right design boutiques and shop windows - all this will help to have a significant impact on the effective results of their work in the same fully applies to the children's range.

Assortment - the problem of specific products, their individual series, determining the relations between "old" and "new" products, products for single and serial production, "High" and

"Normal" goods, goods materialized, or licenses and "know-how". When forming the price range there are problems of quality, warranty, service, whether the manufacturer is going to play a leadership role in the creation of new types of products or forced to follow other manufacturer

The formation range precedes the development of enterprise product line concept. It is aimed to build an optimum assortment structure, commodity supply, with a basis accepted, on the one hand, the consumer demands of certain groups (segments), and with another - the need to ensure the most efficient use of enterprise commodity, technological, financial and other resources in order to manufacture products with low costs.

Assortment concept is expressed in the form of a system of indicators characterizing the possibility of optimal development of the production range of this type of goods. These indicators include: the diversity 


\begin{tabular}{|c|c|c|c|c|c|c|}
\hline \multirow{4}{*}{ Impact Factor: } & ISRA (India) & $=3.117$ & SIS (USA) & $=0.912$ & ICV (Poland) & $=6.630$ \\
\hline & ISI (Dubai, UAE & $=0.829$ & РИНЦ (Russia & $=0.156$ & PIF (India) & $=1.940$ \\
\hline & GIF (Australia) & $=0.564$ & ESJI (KZ) & $=8.716$ & IBI (India) & $=4.260$ \\
\hline & JIF & $=1.500$ & SJIF (Morocce & $=5.667$ & OAJI (USA) & $=0.350$ \\
\hline
\end{tabular}

of species and varieties of goods (taking into account the typology of consumers); the level and frequency of updating of assortment; level and the ratio of the prices of goods of this type, and others. [1]

Planning and assortment management - an integral part of marketing. Even a well-designed marketing and advertising plans will not be able to neutralize the consequences of mistakes made earlier in the planning range.

The optimum range of the structure should ensure maximum return on the one hand and sufficient stability of the economic and market indicators (eg sales volume), on the other hand.

Achieving the highest possible profitability is ensured by continuous monitoring of economic indicators and timely decisions on the adjustment range.

Thus, from the customer's perspective (for relaxing the selection of measurable perception embodiment) range should consist of no more than 57 groups, 5-7 of names, i.e., the entire range in terms of perception optimally should consist of 25 - 50 titles. If the names of more than an objective, the output is only further classification.

It is generally accepted that a wide range of customer needs. This very wide range of often referred to even as a competitive advantage. But in fact it turns out that for a wide range of manufacturer - it's hundreds of types of products, and for the consumer 7 titles have more than enough.

And so the consumer need not wide range and variety required for it.

If the company professes approach a wide range, it is sufficient to carry out sales analysis, look at the statistics, to make sure that the sales leaders are $5-10$, on the strength of $15 \%$ of names, all other positions are sold very little demand for them is insignificant, although costs differ little from cost of sales leaders. The situation turns out, when several items of "feeds" the whole wide range of businesses. And this is not always justified in terms of the completeness of the range (the favorite argument of sellers), that is, the presence of different items to cover the maximum possible options customer needs. In practice, it turns out that the fullness is completely ensured, even if the existing range of cut twice and even three times. The main thing in this case correctly classify all the goods and to ensure that to an assortment of products were submitted from every possible group that classification. And the more reason for the classification of the company can allocate, the more balanced will be a solution. Thus, the classification of goods can be meet customer needs, according to the functional purpose of the goods, for the benefit of the company

Important criterion footwear market competitiveness is its cost with a corresponding its quality and purchasing power of the population.

The main criterion of the viability and profitability of the enterprise is profit, to increase the loss is first necessary to reduce the cost of shoes.

The ratio of the changes in the calculation of each article costs depend on changes in the total cost, which includes all costs of production and sale of shoes.

An important factor affecting the level of costs in the production of shoes is to change the range and the process (Table 1-3). [2]

Table 1. Effect of the implementation of the shoe on the financial condition of the enterprise

\begin{tabular}{|c|c|c|c|c|c|}
\hline \multicolumn{6}{|l|}{ Men's shoes } \\
\hline $\begin{array}{l}\text { volume } \\
\text { realization\% }\end{array}$ & $100 \%$ & $80 \%$ & $60 \%$ & $48 \%$ & $40 \%$ \\
\hline $\begin{array}{l}\text { Gains / Losses } \\
\text { for the month, rub. }\end{array}$ & $824,881.2$ & $207,739.04$ & $190,596.51$ & 0 & $126,545.78$ \\
\hline $\begin{array}{l}\text { tax on } \\
\text { profit } 20 \%\end{array}$ & $164,976.22$ & 41547.8 & 38119.3 & 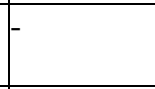 & \\
\hline $\begin{array}{l}\text { Tax } \\
\text { property, } \\
2,2 \%\end{array}$ & 3483.3 & 3483.3 & 3483.3 & 3483.3 & 3483.3 \\
\hline $\begin{array}{l}\text { pure } \\
\text { Profit / loss for the } \\
\text { month, rub. }\end{array}$ & $656,421.7$ & 162708 & 148994 & -3483.3 & -3483.3 \\
\hline $\begin{array}{l}\text { Profit / loss for the year, } \\
\text { rbl. }\end{array}$ & 9898574.4 & $2,492,868.48$ & $2,287,158.12$ & 0 & $1,518,549.36$ \\
\hline $\begin{array}{l}\text { Net profit / loss for the } \\
\text { year, rbl. }\end{array}$ & 7877060.4 & 1952496 & 1787928 & -41799.6 & -41799.6 \\
\hline \multicolumn{6}{|c|}{ Women's shoes } \\
\hline $\begin{array}{l}\text { volume } \\
\text { realization\% }\end{array}$ & $100 \%$ & $80 \%$ & $60 \%$ & $44 \%$ & $40 \%$ \\
\hline Gains / Losses & $1,550,625.12$ & $998,162.35$ & $445,699.56$ & 0 & $-106,763.19$ \\
\hline
\end{tabular}




\begin{tabular}{|c|c|c|c|c|c|c|}
\hline \multirow{4}{*}{ Impact Factor: } & ISRA (India) & $=3.117$ & SIS (USA) & $=0.912$ & ICV (Poland) & $=6.630$ \\
\hline & ISI (Dubai, UAE & $=0.829$ & РИНЦ (Russia & $=0.156$ & PIF (India) & $=1.940$ \\
\hline & GIF (Australia) & $=0.564$ & ESJI (KZ) & $=8.716$ & IBI (India) & $=4.260$ \\
\hline & JIF & $=1.500$ & SJIF (Morocce & $=5.667$ & OAJI (USA) & $=0.350$ \\
\hline
\end{tabular}

\begin{tabular}{|c|c|c|c|c|c|}
\hline for the month, rub. & & & & & \\
\hline $\begin{array}{l}\text { tax on } \\
\text { profit } 20 \%\end{array}$ & $310,125.02$ & $199,632.47$ & 89139.912 & & \\
\hline $\begin{array}{l}\text { Tax } \\
\text { property } \\
2,2 \%\end{array}$ & 3483.3 & 3483.3 & 3483.3 & 3483.3 & 3483.3 \\
\hline $\begin{array}{l}\text { pure } \\
\text { Profit / loss for the } \\
\text { month, rub. }\end{array}$ & 1237017 & $795,046.6$ & $353,076.3$ & -3483.3 & -3483.3 \\
\hline $\begin{array}{l}\text { Profit / loss for the year, } \\
\text { rbl. }\end{array}$ & 18607501 & 11977948 & 5348395 & 0 & $-1,281,158.28$ \\
\hline $\begin{array}{l}\text { Net profit / loss for the } \\
\text { year, rbl. }\end{array}$ & 14844204 & 9540559 & 4236916 & -41799.6 & -41799.6 \\
\hline \multicolumn{6}{|c|}{ Children's shoes } \\
\hline $\begin{array}{l}\text { volume } \\
\text { realization\% }\end{array}$ & $100 \%$ & $90 \%$ & $83 \%$ & $80 \%$ & - \\
\hline $\begin{array}{l}\text { Gains / Losses } \\
\text { for the month, rub. }\end{array}$ & $511,267.68$ & $495,905.15$ & 0 & $-416,365.49$ & \\
\hline $\begin{array}{l}\operatorname{tax} \text { on } \\
\text { profit } 20 \%\end{array}$ & $102,253.54$ & 9918103 & - & & \\
\hline $\begin{array}{l}\text { Tax } \\
\text { property, } 2.2 \%\end{array}$ & 3483.3 & 3483.3 & 3483.3 & 3483.3 & \\
\hline $\begin{array}{l}\text { Net profit / loss for the } \\
\text { month, rub .. }\end{array}$ & $405,530.84$ & 39668929 & -3483.3 & -3483.3 & \\
\hline $\begin{array}{l}\text { Profit / loss for the year, } \\
\text { rbl. }\end{array}$ & 6135212 & 49590515 & 0 & $-4,996,385.88$ & \\
\hline $\begin{array}{l}\text { pure } \\
\text { Profit / loss for the year, } \\
\text { RUR. }\end{array}$ & 4866370 & 39668929 & -41799.6 & -41799.6 & \\
\hline
\end{tabular}

Table 1 shows that at $100 \%$ of sales of shoes provided compensation costs not only for production and sales of shoes, but remains net income, which demonstrates the effectiveness of the company during the analyzed month, as well as the right marketing policy of the enterprise product line. This result of the work will allow the company to distribute the net profit on the formation of a financial reserve, payment of dividends, the development of production, financing of social programs, and others.

Table 2. Summary of results characteristic of survey respondents - children, parents, consumers and manufacturers to assess the competitive potential of the shoe enterprises SFD and North Caucasus Federal District regions

\begin{tabular}{|c|c|c|c|}
\hline children Poll Results & Parents Poll Results & customer survey results & manufacturers Poll Results \\
\hline $\begin{array}{l}2 \text { - The quality of children's } \\
\text { shoes }\end{array}$ & $\begin{array}{l}\text { s - The quality of children's } \\
\text { shoes }\end{array}$ & $\begin{array}{l}3 \text { - The quality of children's } \\
\text { shoes }\end{array}$ & 's 3 - The quality of children's shoes \\
\hline 1 - Form forefoot & 8 - The comfort & 9 - The comfort & 4 - Functionality children's shoes \\
\hline 11 - Weight & 1 - Weight & $\begin{array}{l}6 \text { - Compliance with the } \\
\text { fashion direction }\end{array}$ & 9 - The comfort \\
\hline 5 - Comfort & 7 - Price & 7 - Price & 7 - Price \\
\hline $\begin{array}{l}13 \text { - Materials for the } \\
\text { bottom of shoes }\end{array}$ & e - Flexibility & $\begin{array}{l}\text { four - } \\
\text { Functionality of children's } \\
\text { shoes }\end{array}$ & $\begin{array}{l}6 \text { - Compliance with the fashion } \\
\text { direction }\end{array}$ \\
\hline $\begin{array}{l}22 \text { - Compliance with the } \\
\text { fashion direction }\end{array}$ & $\begin{array}{l}4 \text { - Stability of coloring } \\
\text { materials used for shoe } \\
\text { e uppers to dry and wet } \\
\text { friction and sweat effects }\end{array}$ & e 1 - Weight & $\begin{array}{l}5 \text { - Characterization of materials } \\
\text { for shoe uppers }\end{array}$ \\
\hline
\end{tabular}




\begin{tabular}{|c|c|c|c|c|c|c|}
\hline \multirow{4}{*}{ Impact Factor: } & ISRA (India) & $=3.117$ & SIS (USA) & $=0.912$ & ICV (Poland) & $=6.630$ \\
\hline & ISI (Dubai, UAE & $=0.829$ & РИНЦ (Russia & $=0.156$ & PIF (India) & $=1.940$ \\
\hline & GIF (Australia) & $=0.564$ & ESJI (KZ) & $=8.716$ & IBI (India) & $=4.260$ \\
\hline & JIF & $=1.500$ & SJIF (Morocce & $=5.667$ & OAJI (USA) & $=0.350$ \\
\hline
\end{tabular}

\begin{tabular}{|l|l|}
\hline $\begin{array}{l}4-\text { The price of children's } 2 \text { - Color } \\
\text { shoes }\end{array}$ & $\begin{array}{l}5- \\
\text { characterization } \\
\text { top shoes }\end{array}$
\end{tabular}

21 - The diversity of the 6 - Durability fastening 8 - Characterization of 8 - Characterization of materials range shoes for children inshoe bottom materials for the bottom offor the bottom of shoes shops and

shopping centers

6 - The level of service of 11 - The warranty period 2 - Color parents and children infor children's shoes shops and

shopping centers

\begin{tabular}{|l|l|l|}
\hline $7-$ Color & $\begin{array}{l}\text { ten - } \\
\text { repairability }\end{array}$ & $\begin{array}{l}15-\text { What type of children's } 12 \text { - Maintainability } \\
\text { shoes are preferred: } \\
\text { autumn }\end{array}$ \\
\hline
\end{tabular}

9 - The height of the heel 9 - The deformation of the 10 - Height elation heel of 13 - The warranty period for portion elation -up to 40toe cap and backdrop the shoe - $40 \mathrm{~mm}$ children's shoes $\mathrm{mm}$

15 - Place of sale shoes for children - the interior of the store, or shopping center

8 - The warranty period for children's shoes

16 - What type of children's shoes are preferred: Winter

18 - What type of children's shoes are preferred: spring

12 -

Maintainability children's shoes its expediency

3 - Flexibility children's shoes

10 - The height of the heel of the shoe elation -svyshe $40 \mathrm{~mm}$

17 - What type of children's shoes are preferred:

autumn

20 - Durability fastening shoe bottom 14 - Materials for shoe uppers

19 - What type of children's shoes are preferred:

year

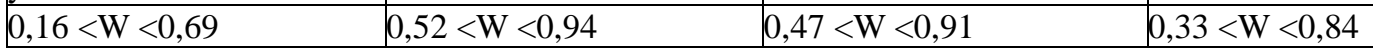

14 - What type of children's 10 - Height elation heel of the shoes are preferred: $\quad$ shoe $-40 \mathrm{~mm}$ winter

11 - The height of the heel 11 - The height of the heel of the part of elation $\quad$ shoe elation -svyshe $40 \mathrm{~mm}$ -svyshe shoe $40 \mathrm{~mm}$ 12 repairability

18 - Durability fastening shoe bottom

16 - What type of children's shoes are preferred: spring

13 - The warranty period for children's shoes

17 - What type of children's shoes are preferred: year 


\begin{tabular}{|c|c|c|c|c|c|c|}
\hline \multirow{4}{*}{ Impact Factor: } & ISRA (India) & $=3.117$ & SIS (USA) & $=0.912$ & ICV (Poland) & $=6.630$ \\
\hline & ISI (Dubai, UAE & $=0.829$ & РИНЦ (Russia) & $=0.156$ & PIF (India) & $=1.940$ \\
\hline & GIF (Australia) & $=0.564$ & ESJI (KZ) & $=8.716$ & IBI (India) & $=4.260$ \\
\hline & JIF & $=1.500$ & SJIF (Morocco) & $=5.667$ & OAJI (USA) & $=0.350$ \\
\hline
\end{tabular}

Table 3. Summary of characteristics of respondents the survey results - the children, their parents, consumers and manufacturers to assess the competitive potential of the shoe enterprises SFD and North Caucasus Federal District regions, but without heretics, whose opinion does not coincide with the majority of respondents to the survey

\begin{tabular}{|c|c|c|c|}
\hline $\begin{array}{l}\text { poll results } \\
\text { children }\end{array}$ & $\begin{array}{l}\text { poll results } \\
\text { parents }\end{array}$ & $\begin{array}{l}\text { poll results } \\
\text { buyers }\end{array}$ & $\begin{array}{l}\text { poll results } \\
\text { producers }\end{array}$ \\
\hline $\begin{array}{l}2 \text { - Quality of child } \\
\text { shoes }\end{array}$ & 7 - Price & $\begin{array}{l}6 \text { - Compliance } \\
\text { trends in fashion }\end{array}$ & $\begin{array}{l}3 \text { - The quality of children's } \\
\text { shoes }\end{array}$ \\
\hline 5 - Comfort & 8 - The comfort & 9 - The comfort & $\begin{array}{l}4 \text { - Functionality } \\
\text { children's shoes }\end{array}$ \\
\hline \begin{tabular}{|l|l}
$11-$ Weight & 1 \\
\end{tabular} & 1 - Weight & 7 - Price & 7 - Price \\
\hline $\begin{array}{l}22 \text { - Compliance with the } 3 \\
\text { fashion direction }\end{array}$ & $\begin{array}{l}3-\text { The quality of } 3 \\
\text { children's shoes }\end{array}$ & 3 - The quality of children's shoes & 9 - The comfort \\
\hline $\begin{array}{l}16 \quad-\quad \text { What type } \text { of } 5 \\
\text { children's shoes are } \\
\text { preferred: } \\
\text { winter }\end{array}$ & 5 - Flexibility & $\begin{array}{l}15 \text { - What type of children's } \\
\text { shoes are preferred: autumn }\end{array}$ & $\begin{array}{l}6 \text { - Compliance with the } \\
\text { fashion direction }\end{array}$ \\
\hline \multirow{2}{*}{\multicolumn{2}{|c|}{\begin{tabular}{|l|l|}
$\begin{array}{l}6-\text { The level of service of } 4 \text { - Color fastness used for } 1 \\
\text { parents and children in shoe uppers } \\
\text { shops and } \\
\text { materials to }\end{array}$ \\
& $\begin{array}{l}\text { dry and wet abrasion and } \\
\text { exposure to sweat }\end{array}$ \\
\end{tabular}}} & 1 - Weight & $\begin{array}{l}12- \\
\text { repairability }\end{array}$ \\
\hline & & & \\
\hline $\begin{array}{l}21 \text { - The diversity of the } 2 \\
\text { range shoes for children in } \\
\text { shops and } \\
\text { shopping centers }\end{array}$ & $2-$ Color & $\begin{array}{l}14 \text { - What type of children's } \\
\text { shoes are preferred: Winter }\end{array}$ & $\begin{array}{l}5-\quad \text { Characterization of } \\
\text { materials for shoe uppers }\end{array}$ \\
\hline $\begin{array}{l}4 \text { - The price of children's } 6 \\
\text { shoes }\end{array}$ & $\begin{array}{l}6 \text { - bottom fastening } 4 \\
\text { strength } \\
\text { shoes }\end{array}$ & 4 - Functionality children's shoes & $\begin{array}{l}8-\text { Characterization of } \\
\text { materials for the bottom } \\
\text { shoes }\end{array}$ \\
\hline 7 - Color & $\begin{array}{l}\text { ten - } \\
\text { repairability }\end{array}$ & $\begin{array}{l}5 \text { - Feature } \\
\text { materials for shoe uppers }\end{array}$ & 1 - Weight \\
\hline 1 - Form forefoot & $\begin{array}{l}11 \text { - The warranty period } 1 \\
\text { for children's shoes }\end{array}$ & $\begin{array}{l}11 \text { - Height elation heel of the } \\
\text { shoe } 40 \text {-svyshe } \\
\text { mm }\end{array}$ & $\begin{array}{l}13 \text { - The warranty period for } \\
\text { children's shoes }\end{array}$ \\
\hline $\begin{array}{l}12- \\
\text { repairability } \\
\text { children's shoes its } \\
\text { expediency }\end{array}$ & $\begin{array}{l}9 \text { - The deformation of the } 2 \\
\text { toe cap and backdrop }\end{array}$ & 2 - Color & 2 - Color \\
\hline $\begin{array}{l}8 \text { - The warranty period for } \\
\text { children's shoes }\end{array}$ & & $\begin{array}{l}8-\text { Characterization of materials } \\
\text { for the bottom of shoes }\end{array}$ & $\begin{array}{l}10-\text { The height of the heel of } \\
\text { the shoe elation } \\
-40 \mathrm{~mm}\end{array}$ \\
\hline $\begin{array}{l}13 \text { - Materials for the } \\
\text { bottom of shoes }\end{array}$ & & $\begin{array}{l}10 \text { - Height elation heel of the } \\
\text { shoe }-40 \mathrm{~mm}\end{array}$ & $\begin{array}{l}11-\text { Height of elevation of } \\
\text { the heel of the shoe - } \\
\text { over } 40 \mathrm{~mm}\end{array}$ \\
\hline $\begin{array}{l}15 \text { - Place of sale shoes for } \\
\text { children - the interior of } \\
\text { the store, or shopping } \\
\text { center }\end{array}$ & & $\begin{array}{l}16 \text { - What type of children's } \\
\text { shoes are preferred: spring }\end{array}$ & \\
\hline $\begin{array}{l}18-\text { What type of } \\
\text { children's shoes is given } \\
\text { preference: spring }\end{array}$ & & $\begin{array}{l}17 \text { - What type of children's } \\
\text { shoes are preferred: Summer }\end{array}$ & \\
\hline $\begin{array}{l}3 \text { - Flexibility of child } \\
\text { shoes }\end{array}$ & & $\begin{array}{l}18 \text { - Durability fastening } \\
\text { shoe bottom }\end{array}$ & \\
\hline
\end{tabular}




\begin{tabular}{|c|c|c|c|c|c|c|}
\hline \multirow{4}{*}{ Impact Factor: } & ISRA (India) & $=3.117$ & SIS (USA) & $=0.912$ & ICV (Poland) & $=6.630$ \\
\hline & ISI (Dubai, UAI & $=0.829$ & РИНЦ (Russia & $=0.156$ & PIF (India) & $=1.940$ \\
\hline & GIF (Australia) & $=0.564$ & ESJI (KZ) & $=8.716$ & IBI (India) & $=4.260$ \\
\hline & JIF & $=1.500$ & SJIF (Morocco & $=5.667$ & OAJI (USA) & $=0.350$ \\
\hline
\end{tabular}

\begin{tabular}{|l|l|l|}
\hline $\begin{array}{l}19-\text { What type of } \\
\text { children's shoes are } \\
\text { preferred: } \\
\text { year }\end{array}$ & 12 - Maintainability & \\
\hline $\begin{array}{l}14-\text { Materials for shoe } \\
\text { uppers }\end{array}$ & $\begin{array}{l}13 \text { - The warranty period for } \\
\text { children's shoes }\end{array}$ & \\
\hline $\begin{array}{l}9 \text { - The height of the heel } \\
\text { portion elation -up } \\
40 \mathrm{~mm}\end{array}$ & & \\
\hline $\begin{array}{l}10-\text { The height of the heel } \\
\text { portion elation } \\
\text {-svyshe shoe } 40 \mathrm{~mm}\end{array}$ & & \\
\hline $\begin{array}{l}20-\text { Durability fastening } \\
\text { shoe bottom }\end{array}$ & & \\
\hline $\begin{array}{l}17-\text { What type of } \\
\text { children's shoes are } \\
\text { preferred: } \\
\text { autumn }\end{array}$ & & \\
\hline $0,16<\mathrm{W}<0,69 \quad 0,52<\mathrm{W}<0,94$ & $0,47<\mathrm{W}<0,91$ & $0,33<\mathrm{W}<0,84$ \\
\hline
\end{tabular}

The market conditions of managing an effective management system requires a rational organization of the sales activity, which largely determines the enterprise level of use of means of production, labor productivity, reduce production costs, increase profits and profitability. This is due to the fact that marketing activities - this is not only the sale of finished shoes, but also the orientation of production to meet the demand of buyers solvency and active work in the market for the maintenance and development of the demand for the company's products, and the organization of efficient channels of distribution and promotion of products.

Thus, shoe company in the development range policy should be oriented both external (price and consumer niche, competing companies market conjecture et al.), And internal factors such as sales volume, profitability, covering the basic cost et al. [3]

Assortment policy is to develop the implementation of decisions regarding nomenclature (names) of products, variety of assortment of names, the need to expand the range of manufactured.

Analysis results survey respondents on the criteria for assessing the competitiveness of and demand for children's shoes with the participation of children, their parents, buyers and manufacturers have confirmed the expected result, namely, the fact that the competence of the survey participants differ greatly among themselves and do not allow to take one only right decision about the actual criteria of competitiveness assessment and the demand by type of footwear for the entire product range. Designed by the authors of the software for the distribution of all the participants in the survey on the extent of their competence on the mentioned process using the concordance coefficient has confirmed its high efficiency for all participants in the survey. [3]
Less expertise have natural children, because they have in completing the questionnaire in the first place, such criteria were defined as the mass of the comfort variety of assortment of shoes in a store, service levels, and not those who warn of the child and the parents of the possible formation of their child pathological foot abnormalities. The results of the survey of parents do not have a high compactness of the criteria for assessing the competitiveness of and demand for children's shoes, but they are united by the desire to see in-store quality footwear, in which they put the following understanding: comfort, weight, price and warranty period, although rapidly growing baby feet, this factor is less important. But maybe this is the voice of the parents in a family where three or more children with no significant difference in age. Surprised by the survey results of those buyers who consciously choose to shop with children's footwear, and the desire to buy a shoe, which is necessary for their child, it is possible to speak of a conscious choice. Confirmation of our assumptions is the fact that consumers, both men and women were unanimous in saying that the children's shoes should be comfortable, easy and affordable. But on the other hand it confirmed the fact that having a lack of competence and consistency in the evaluation criteria of competitiveness and demand for children's shoes, while they assessed the available in-store product range of footwear exclusively with consumer products. And almost no attention to the criteria that would protect their children from the foot of formation of pathological abnormalities. Sadly, doctors, orthopedists in institutions is not enough pay attention to outreach to parents, provoking them to a more informed decision about buying shoes to your child, preferring a shoe that all and only all criteria would ensure a child, his warning the foot, from the formation of pathological deviations . Were only 


\begin{tabular}{|c|c|c|c|c|c|c|}
\hline \multirow{4}{*}{ Impact Factor: } & ISRA (India) & $=3.117$ & SIS (USA) & $=0.912$ & ICV (Poland) & $=6.630$ \\
\hline & ISI (Dubai, UAE & $=0.829$ & РИНЦ (Russia & $=0.156$ & PIF (India) & $=1.940$ \\
\hline & GIF (Australia) & $=0.564$ & ESJI (KZ) & $=8.716$ & IBI (India) & $=4.260$ \\
\hline & JIF & $=1.500$ & SJIF (Morocce & $=5.667$ & OAJI (USA) & $=0.350$ \\
\hline
\end{tabular}

competent answers to the questionnaire on the criteria for assessing the competitiveness of and demand for children's footwear manufacturing representatives. Their criterion - quality children's shoes, children's shoes functionality, comfort, weight, material properties for the top and bottom of footwear, confirms their understanding of the importance of compliance with state standards and technical regulations governing the conditions to guarantee the execution of children is not only a comfortable stop, but also protects it from the formation of pathological abnormalities. Pleases and the fact that their competence has a high level of consistency with other experts, as evidenced by the high concordance rate value (W), close to unity. That is, parents have every reason to get shoes made by manufacturers, knowing that their children's foot is not in danger.

In the South and the North - Caucasian Federal Districts is quite mild climate, most of the market is saturated views of shoes of the same purpose. heads of enterprises need to know exactly what the market will demand and how this should be implemented to develop a range of shoes has been selected by the buyer, withstanding fierce competition, generating new proposals.

For all this, so it is important to build the assortment policy, to the market, if and enters shoe of the same type, it must differ substantially in price, but conform to its requirements. The success of the enterprise in the market depends not only on the location of the segment, but also on finding the unallocated space on the market - a niche market. It is believed that the company operating in niches, so knows and is able to satisfy the needs and requirements of buyers niche that past are willing to pay for the goods (services) of the company, even higher price. Occupation niche have a chance to compete by focusing its resources on serving a narrow niche markets that do not cause interest or who do not pay attention to larger companies - competitors. innovative technology used in the manufacture of shoes, that increase the functionality of the production. This makes it possible in the case of a surplus production of one type of shoe, upload production of other, more popular. Innovation innovation in engineering, technology, work organization and management, based on the use of science and excellence, providing high-quality production system efficiency and product quality. Planning and assortment management - an integral part of marketing. Even a well-designed marketing and advertising plans will not be able to neutralize the consequences of mistakes made earlier in the planning range. The optimum range of the structure should ensure maximum return on the one hand, and sufficient stability of the economic and market indicators (eg sales volume) - on the other. In the future, the following scenarios of development of the external environment, the probability of which is estimated the company's management as follows: increase in purchasing power (scenario S1, the probability of occurrence - 0.2 ); immutability of purchasing power of the population and the impact of foreign competitors ( $\mathrm{S} 2$ scenario, the probability of occurrence - 0.5); decrease in purchasing power due to inflation growth at constant competition ( $\mathrm{S} 3$ scenario, the probability of occurrence - 0.3).

For more information, to make the necessary calculations:

- the cost of living - 11924 rubles.

- daily output - 576 pairs of shoes;

- population - 100 people, who are engaged in the release of 576 pairs of shoes a day.

- at week 5 working days, the total number of working days per year - 250 days;

- monthly production of footwear - 12,000 pairs;

- the annual output of 144,000 pairs of shoes.

We assume that the average cost of one pair of shoes at constant purchasing power (S2 scenario) will be characterized by the following values: the price of a pair of expensive shoes for the target audience with high income of 5 thousand rubles; the price of a pair of shoes for the target audience with earnings above the minimum subsistence level - 2 thousand rubles; the price of a pair of cheap shoes for socially protected layers with earnings below subsistence level - 1 thousand rubles.

The total sales volume of footwear at constant purchasing power (S2 scenario) will be considered for the audience:

the implementation of expensive shoes for the target audience with high income - 60 million rubles. per month;

the implementation of the shoe to the target audience with earnings above the subsistence minimum - 24 million rubles. month;

the implementation of cheap shoes for socially protected layers with earnings below the subsistence minimum - 12 million rubles. per month.

For the target audience with the growth of purchasing power (S1 scenario), the price of a pair of expensive shoes will be 5 thousand rubles, the price of one pair of shoes for the target audience with earnings above the minimum subsistence level -.... 3 thousand rubles, the price of one pair of shoes for unprotected layers - 1 ths. rub.

For the target audience with low purchasing power ( 33 scenario), the price of one pair of shoes is expensive 2.5 th RUB, the price of one pair of shoes for the target audience with earnings above subsistence -... 1 th RUB, the price of one pair of shoes for the unprotected layers - 500 rubles.

For each of the scenarios under consideration calculated the volume of sales of shoes per month.

We carried out a calculation of the sum of the mathematical expectations of the realization volume 


\begin{tabular}{|c|c|c|c|c|c|c|}
\hline \multirow{4}{*}{ Impact Factor: } & ISRA (India) & $=3.117$ & SIS (USA) & $=0.912$ & ICV (Poland) & $=6.630$ \\
\hline & ISI (Dubai, UAI & $=0.829$ & РИНЦ (Russia & $=0.156$ & PIF (India) & $=1.940$ \\
\hline & GIF (Australia) & $=0.564$ & ESJI (KZ) & $=8.716$ & IBI (India) & $=4.260$ \\
\hline & JIF & $=1.500$ & SJIF (Morocco & $=5.667$ & OAJI (USA) & $=0.350$ \\
\hline
\end{tabular}

taking into account the likelihood of the three scenarios. Management companies based on their experience or analysis (intuitively), estimate the probability of occurrence of a situation [2].

Separately for each strategy is determined by the sum of the mathematical expectations of the sales volumes of the product of footwear sales volume per month in the implementation of each scenario on its probability.

On the calculation of the amount of the expectation of sales volume, the maximum sales volume gained expensive footwear production strategy for the target audience with high income.

Summing up the information obtained as a result of the study, formulated as a block diagram the formation of mentality. The proposed structuring can be used when planning range for industrial and SFD NCFD regions. It was only in the relationship of all the factors considered above can be argued about the high stability of the financial performance of the shoe enterprises regions of the Southern Federal District and North Caucasus Federal District, united in the Innovation Center.

In our case, the traditional pattern formation range pawned differentiation based on the classification of footwear on three grounds:

purpose (home; special);

sex and age (base - GOST 3927-88 shoe shoes booties for toddlers, small children, preschool, forgirls school, maiden, for-school boys, boys', women's, men's.);

operating conditions (kind of professional activity, seasonality, climatic zone);

Based on other sources, shoes for their intended purpose can be divided into domestic (daily, model, homemade) and (industrial, sports, orthopedic, medical). However, such a division of the range has a number of significant drawbacks. It does not allow to identify groups of people with different styles, quality of life and taste preferences. The division also by sex and age meant different anthropometric characteristics of consumers according to age and gender, but do not take into account age differences in lifestyle and needs priorities. Needs of the population in the goods pawned historically. They are determined by the level of development of social production, welfare and culture of the society and can change over time. range of features include a concept as mobility. By definition, mobility marketing - urgent implementation of decisions adopted, studies within strict deadlines. The use of the term "mobility" in relation to the shoe assortment is rapid turnover of models range, depending on market conditions and customer requirements, imposed on shoes.

Formation of shoe assortment in view of its competitiveness - is a complex process which is carried out taking into account the actions of a number of factors, the study of which should be based on an analysis of the current footwear market, as well as forecasting trends in the social, economic and industrial fields.

The formation range precedes the development of enterprise product line concept. It is aimed to build an optimum structure of the shoe of high quality products, at the same time shall be based on the one hand, the need to ensure the most effective use of enterprise commodity, technological, financial and other resources in order to manufacture products with low costs, and on the other - to meet the requirements certain groups of consumers with regard to their features and capabilities. [3]

To create a competitive high quality products shoe enterprises need to expand and update the range, to provide a high turnover dynamics models, to increase the volume and improve the efficiency of the model-design studies, quality and satisfaction of the population of footwear.

When developing or updating a range of footwear, the company is obliged to take into account not only the possibilities, but also the presence in the market of similar footwear competing firms, as well as the preferences of customers in selected segments.

You can not talk about the quality and competitiveness of footwear in general without taking into account the needs of a specific group of buyers in the markets of the appropriate type. Markets footwear goods are a diverse set of customers with different tastes and preferences.

Activities on the allocation of potential user groups of specific types of goods is called market segmentation. Segmentation focuses on the differences in the behavior of different types of buyers (customers) in their respective markets. For shoe enterprises segmentation of customers is the basis for the adjustment of the existing structure of the assortment of shoes or to develop new models. Footwear is one of the most important products manufactured light industry of the Russian Federation and imported from abroad. On the correct determination of the quantity and quality models produced footwear enterprises, the competitiveness of the range depends on the degree of satisfaction of consumers demand, profitability and profitability of organizations. The result of the interaction of the components of the market (demand, supply,

Thus, the value of the footwear market is to meet the needs of the population. Accordingly, the development of the market leads to increased levels of security individual member of society. Markets consist of buyers, and buyers differ in a variety of settings: according to his needs, financial and other capabilities, location, customer's attitudes and buying habits. In this sense, the South and the North -Kavkaz federal districts of greatest interest to the market segmentation due to the homogeneity of the aggregate consumer responds to the same goods and the means of evaluating for purchase. Characteristics of the market segmentation of regions presented in Tables 4 


\begin{tabular}{|c|c|c|c|c|c|c|}
\hline \multirow{4}{*}{ Impact Factor: } & ISRA (India) & $=3.117$ & SIS (USA) & $=0.912$ & ICV (Poland) & $=6.630$ \\
\hline & ISI (Dubai, UAE & $=0.829$ & РИНЦ (Russia & $=0.156$ & PIF (India) & $=1.940$ \\
\hline & GIF (Australia) & $=0.564$ & ESJI (KZ) & $=8.716$ & IBI (India) & $=4.260$ \\
\hline & JIF & $=1.500$ & SJIF (Morocce & $=5.667$ & OAJI (USA) & $=0.350$ \\
\hline
\end{tabular}

and 5. Given the climatic features of the two districts, namely, relatively mild and humid climate in winter, High temperature in summer and comfortable in autumn and spring, it is necessary, taking into account these features form the assortment policy of manufacturing such a product range of footwear to guarantee its supply and demand is not only due to the pricing policy, but also to provide consumers, especially children, comfort and the occurrence of a warning of pathological deviations stop. Unfortunately, today the imported products market content does not ensure the elimination of these problems that provokes import substitution shoes to meet the demand of consumers of these subjects is in a shoe that would satisfy them in all aspects, and to manufacturers - to provide sustainable technical and economic indicators guarantee social protection of the population in these regions. When segmenting the enterprise market is divided large heterogeneous markets into smaller (and more uniform) segments, which can be serviced more efficiently, according to the specific needs of these segments. Shoe factories for the successful implementation of output is first necessary to produce segmentation of the consumer market and to identify the target segment of the market. In general sense, market segmentation refers to the process of market division into groups of consumers of certain signs of advance, allowing you to concentrate on the most effective means of market segment. segment of the market - a uniform set of consumers are equally responsive to goods and means of its presentation. in accordance with the specific needs of these segments. Shoe factories for the successful implementation of output is first necessary to produce segmentation of the consumer market and to identify the target segment of the market. In general sense, market segmentation refers to the process of market division into groups of consumers of certain signs of advance, allowing you to concentrate on the most effective means of market segment. segment of the market - a uniform set of consumers are equally responsive to goods and means of its presentation. in accordance with the specific needs of these segments. Shoe factories for the successful implementation of output is first necessary to produce segmentation of the consumer market and to identify the target segment of the market. In general sense, market segmentation refers to the process of market division into groups of consumers of certain signs of advance, allowing you to concentrate on the most effective means of market segment. segment of the market - a uniform set of consumers are equally responsive to goods and means of its presentation. In general sense, market segmentation refers to the process of market division into groups of consumers of certain signs of advance, allowing you to concentrate on the most effective means of market segment. segment of the market - a uniform set of consumers are equally responsive to goods and means of its presentation. In general sense, market segmentation refers to the process of market division into groups of consumers of certain signs of advance, allowing you to concentrate on the most effective means of market segment. segment of the market - a uniform set of consumers are equally responsive to goods and means of its presentation.

Target segment (market) - a segment selected from the study of a commodity market of a product or service has a minimum cost of means of moving goods and provides businesses the bulk of its activity results (profits or other criteria exit objectives of the enterprise on the market). Market segmentation of footwear in the Southern and North Caucasus Federal District can be carried out on the basis of, and consistent with the use of several indicators

The results of the segmentation of the analyzed basic footwear market of the South and the North Caucasian Federal District, can be represented as a table of ratings. Segment, collected as a result of the minimum amount of seats is the most appealing.

An analysis of Tables 4 and 5 revealed a single republic, the city of federal purpose, two edges and three areas where there is the greatest consumer market segmentation of the two districts: Republic of Crimea - 2.25. Sevastopol - 2.4. Rostov region $-2.5 \%$, Krasnodar - 2.65\%, Astrakhan region - $2.7 \%$ Volgograd region - 3.25\%, Stavropol - 5.4\%.

However, during the segmentation must take into account the target segmentation. [4]

When creating new enterprises in the regions of the Southern Federal District and the North Caucasian Federal District for the production of footwear products must be based on demand for the entire product range of the shoe, to provide consumers in these regions in demand and competitive products.

Table 4. Results of the segmentation of the consumer market by the SFD amount of seats, taking into account weighting coefficients

\begin{tabular}{|c|c|c|c|c|c|c|}
\hline \multirow[b]{2}{*}{ Name territorial unit } & \multirow[b]{2}{*}{$\begin{array}{l}\text { Population } \\
\text { thousand. } \\
\text { People. }\end{array}$} & \multirow[b]{2}{*}{$\begin{array}{l}\text { Square, } \\
\mathrm{km} 2\end{array}$} & \multicolumn{4}{|c|}{ rating position } \\
\hline & & & $\begin{array}{l}\text { profitability } \\
\text { score } \times \\
0,45\end{array}$ & $\begin{array}{l}\text { salary, } \\
\text { score } \\
0,30\end{array}$ & $\begin{array}{l}\text { number, } \\
\text { rating } \times 0,25\end{array}$ & $\begin{array}{l}\text { sum } \\
\text { points } \%\end{array}$ \\
\hline \multicolumn{7}{|c|}{ Southern Federal District, in. including } \\
\hline Republic of Adygea & 451.5 & 7792 & 3.6 & 2.1 & 2.75 & 8.45 \\
\hline
\end{tabular}




\begin{tabular}{|c|c|c|c|c|c|c|}
\hline \multirow{4}{*}{ Impact Factor: } & ISRA (India) & $=3.117$ & SIS (USA) & $=0.912$ & ICV (Poland) & $=6.630$ \\
\hline & ISI (Dubai, UAE & $=0.829$ & РИНЦ (Russia & $=0.156$ & PIF (India) & $=1.940$ \\
\hline & GIF (Australia) & $=0.564$ & ESJI (KZ) & $=8.716$ & IBI (India) & $=4.260$ \\
\hline & JIF & $=1.500$ & SJIF (Morocce & $=5.667$ & OAJI (USA) & $=0.350$ \\
\hline
\end{tabular}

\begin{tabular}{|l|l|l|l|l|l|l|}
\hline Astrakhan region & 1018.6 & 49024 & 0.9 & 0.3 & 1.5 & 2.7 \\
\hline Volgograd region & 2545.9 & 112877 & 1.35 & 0.9 & 1.0 & 3.25 \\
\hline Republic of Kalmykia & 278.8 & 74731 & 4.95 & 2.4 & 3.25 & 10.6 \\
\hline Krasnodar region & 5513.8 & 75485 & 1.8 & 0.6 & 0.25 & 2.65 \\
\hline Republic of Crimea & 1907.1 & 26100 & 1.3 & 0.5 & 0.45 & 2.25 \\
\hline Rostov region cederal city of & 4236.0 & 100967 & 0.65 & 1.25 & 0.6 & 2.5 \\
\hline $\begin{array}{l}\text { The fed.3 } \\
\text { Sevastopol }\end{array}$ & 864 & 1.65 & 0.55 & 0.2 & 2.4 \\
\hline Total & 16368.0 & 447821 & & & & \\
\hline
\end{tabular}

Table 5. Results of the segmentation of the consumer market of North Caucasus Federal District by the sum of places, taking into account weighting coefficients

\begin{tabular}{|c|c|c|c|c|c|c|}
\hline \multirow[b]{2}{*}{ Name territorial unit } & \multirow{2}{*}{$\begin{array}{l}\text { Population } \\
\text { thousand. } \\
\text { People. }\end{array}$} & \multirow[t]{2}{*}{ Area, km2 } & \multicolumn{4}{|c|}{ rating position } \\
\hline & & & $\begin{array}{l}\text { profitability } \\
\text { score } \quad \times \\
0,45\end{array}$ & $\begin{array}{l}\text { salary, } \\
\text { score } \times \\
0,30\end{array}$ & $\begin{array}{l}\text { number, } \\
\text { rating } \times 0,25\end{array}$ & $\begin{array}{l}\text { sum } \\
\text { points\% }\end{array}$ \\
\hline \multicolumn{7}{|c|}{ North - Caucasian Federal District, including } \\
\hline The Republic of Dagestan & 3015.7 & 50270 & 4.5 & 3.9 & 1.25 & 9.65 \\
\hline The Republic of Ingushetia & 0,473 & 3628 & 5.4 & 1.8 & 2.5 & 9.7 \\
\hline Kabardino-Balkar Republic & 0.862 & 12470 & 2.7 & 3.6 & 1.75 & 8.05 \\
\hline Karachay-Cherkess Republic & 0,468 & 14277 & 4.05 & 3.3 & 3 & 10.35 \\
\hline $\begin{array}{l}\text { Republic of North Ossetia - } \\
\text { Alania }\end{array}$ & 0.704 & 7987 & 2.25 & 3.0 & 2.0 & 7.25 \\
\hline Stavropol region & 2,802 & 66160 & 3.15 & 1.5 & 0.75 & 5.4 \\
\hline Chechen Republic & 1,394 & 15647 & 5.85 & 2.7 & 2.25 & 10.8 \\
\hline Total & 9718 & 170439 & & & & \\
\hline
\end{tabular}

As a result, segmentation is determined that the population of the two districts are unevenly distributed over the territory. Income of the population is much less than the average for Russia. At formation of assortment of shoes should also consider the fact that a large proportion of the population - the villagers. In addition, it is necessary to take into account national peculiarities of the inhabitants of these entities and their traditions.

For efficient operation of domestic enterprises for the production of competitive children's footwear appropriate to provide for the use of innovative flexible manufacturing processes, the use of universal and multi-functional equipment, a variety of methods for attaching the shoe bottom, drill shoe manufacturing TEHOSNASTKA, fittings, production of auxiliary materials, which will significantly reduce the cost of its production and improve the competitiveness not only in the markets of the South the second and the North - Caucasian Federal District (SFD and North Caucasus Federal District), but also on the domestic markets of other regions of Russia, guaranteeing it a steady supply and implementation, thereby providing less painful and more efficient replacement of the same model shoe on the other,
The strategy of production of competitive products from the skin will be organized production of shoes with not only mechanized innovative processes using nanotechnology, but that is especially in demand for SFD and North Caucasus Federal District - the use of manual labor, which is due to the desire of manufacturers to meet the demand for exclusive products not only for the elite, but also for consumers. [4] points:

Forming range includes the following main

- identifying current and future customer needs, analysis of ways to use the features of the footwear and consumer behavior in the relevant market;

- Assessment of the existing analogue competitors;

- critical evaluation of products now manufactured in the same range, but with the position of the buyer;

- issues, what products should be added to the range, and which are excluded from it because of changes in the level of competitiveness; whether to diversify production at the expense of other areas of the enterprise production beyond its existing profile; 


\begin{tabular}{|c|c|c|c|c|c|c|}
\hline \multirow{4}{*}{ Impact Factor: } & ISRA (India) & $=3.117$ & SIS (USA) & $=0.912$ & ICV (Poland) & $=6.630$ \\
\hline & ISI (Dubai, UAI & $=0.829$ & РИНЦ (Russia & $=0.156$ & PIF (India) & $=1.940$ \\
\hline & GIF (Australia) & $=0.564$ & ESJI (KZ) & $=8.716$ & IBI (India) & $=4.260$ \\
\hline & JIF & $=1.500$ & SJIF (Morocco & $=5.667$ & OAJI (USA) & $=0.350$ \\
\hline
\end{tabular}

- Consideration of proposals for the creation of new models of shoes, the improvement of existing ones;

- Development of specifications for new or improved models in accordance with customer requirements;

- studying possibilities of production of new or improved models, including price issues, cost and profitability;

- testing (testing) Shoe considering potential consumers in order to determine their admissibility on the basic parameters;

- Develop specific recommendations for manufacturing companies about the quality of units, style, price, name, packaging, service, etc. in accordance with results of tests conducted to confirm the acceptability of the product specifications or predetermining the need to change them.

Thus, from the customer's perspective (for relaxing the selection of measurable perception embodiment) range should consist of no more than 57 groups, 5-7 of names, i.e., the entire range in terms of perception optimally should consist of 25-50 names. If the names of more than an objective, the output is only further classification. It is generally accepted that a wide range of customer needs. This very wide range of often referred to even as a competitive advantage. But in fact it turns out that for a wide range of manufacturer - it's hundreds of types of products, and for the consumer - 7 titles have more than enough. Thus, the user need not wide range and variety required for it. If the enterprise is aimed at a wide range, it is sufficient to carry out sales analysis, to ensure that the sales leaders are 5-10\%. All other items are sold very little demand for them is small, although the costs are little different from the cost of sales leaders. The situation turns out, when several items of "feeds" the whole wide range of businesses. And this is not always justified in terms of the completeness of the range (the favorite argument of sellers), ie represent different denominations to cover the maximum possible choices of customers. In practice, it turns out that the fullness is completely ensured, even if the existing range of cut twice and even three times. The main thing in this case correctly classify all the goods and to ensure that in the assortment were presented products of each possible group of this classification. And the more reason for the classification of the company can allocate, the more balanced will be a solution. Thus, the classification of goods can be meet customer needs, according to the functional purpose of the goods, according to the sales profit. Of particular importance in this situation is the role played by certain range of positions. To this end, the products can be classified into the following groups: A - main product groups (which bring the basic income and are in the growth stage); B - supports groups of goods (goods that stabilize sales revenues and are in a stage of maturity);
In - a strategic group of products (goods, to ensure future profit of the company); D - the tactical group of products (goods, intended to encourage the sale of the main product group and are at the stage of growth and maturity); D - developed by a group of goods (goods that are not present on the market, but are ready to exit the market); E - products, leaving the market (which are not profitable and should be removed from the production output from the market). After that, it is necessary to determine the share of each group in the total volume of production. For sustainable enterprise position in the structure of the range of product groups A and B should be not less than $70 \%$.

Thus, this makes it possible to evaluate the available assortment set in the enterprise and, by relating it to make a profit, to assess the correctness of assortment planning, its balance.

Implementation of the authors of the proposed measures would lead to the elimination of the deficit on the domestic children's shoes, making it not only and not so much competitive, and relevant, but the main thing - a safe and comfortable for the child's foot, guaranteeing him protection against the formation of pathological abnormalities.

Prolonged recession in the Russian economy has: two ways of explanation. The first - the people have lost the ability to work well, squandered "human capital", the second - control helpless. The media claim that politicians know their stuff, keep things under control, take the necessary measures and promise to change for the better in the near future. Hence, the reason is the poor performance of the performers and the unfavorable world market conditions.

How much you have to be naive to planning economic policies, based on sincerity, selflessness, compassion competitors? The Russian president has long said that our Western partners do not want to strengthen Russia, they need obedient Russia, such as the Baltic republics of the former USSR. I did not want to sadden the politicians responsible for the economy, but, according to Aristotle, forced to admit: "Friends of the East too canny" - meaning "Plato is my friend, but truth is more expensive." They will help us at least benefit from such assistance itself.

It is time to realize that all the economic and political alliances in the modern world space - is an attempt to achieve national win in an environment of transnational relations, ie, partners can count on until it is advantageous cooperation. Which implies the conclusion - you need to stand face to its economy. Only in this way, even with a lot of stress, it is able to solve their problems. There is, for example, these objective reasons that would justify the decline in production for over a quarter century in the light industry.

Light industry is closely related to agriculture, really dependent on the work of the latter. Only to such interactions must be approached historically 


\begin{tabular}{|c|c|c|c|c|c|c|}
\hline \multirow{4}{*}{ Impact Factor: } & ISRA (India) & $=3.117$ & SIS (USA) & $=0.912$ & ICV (Poland) & $=6.630$ \\
\hline & ISI (Dubai, UAE & $=0.829$ & РИНЦ (Russia & $=0.156$ & PIF (India) & $=1.940$ \\
\hline & GIF (Australia) & $=0.564$ & ESJI (KZ) & $=8.716$ & IBI (India) & $=4.260$ \\
\hline & JIF & $=1.500$ & SJIF (Morocce & $=5.667$ & OAJI (USA) & $=0.350$ \\
\hline
\end{tabular}

specific, relying on scientific and dialectical analysis. There are old meteoraschety showing that of the 10 calendar years in Russia 5 unfavorable for the development of agricultural production $(2+3$ and $3+$ 2). In determining the "Five-Year Plan" as a planning measures were based on this pattern.

The problems of agriculture and light industry is not in their specificity, they have always been political. In the United States, Europe, farmers have a lot of our problems. The difference is that there is a farmer - a national problem among the most important, fundamental. Its important for consideration of the existence of politicians. On how the policy is to promote a settlement, estimated public places policies. Farmer and politician linked economic policy. They balance on one taut economic stress "rope" viability.

Nothing similar in Russia. Recall the story of the last of Agriculture Ministers. In the Soviet Union there was the Ministry of Light Industry, which emphasized the importance of the industry. What prevents the importance in terms of import declarations and to develop its own production to restore equality in industrial control. "Calico edge" without light industry still that his own nature without birch groves or lyric poetry without creativity Esenin.

Reformers 1990 fate Homeland domestic and industrial care less identity. They lined up on the ease of business to maximize profits and walrus placed away from their ancestral lands. Light industry has traditionally been a difficult problem to manage. Managers need to be, above all, patriots, or light industry did not raise. understanding of "long money" national importance it is also necessary. Compensating the difficulties to become demand stability.

Whatever the economic situation did not develop extremely dangerous absolute value of economic criteria, give them the property of universality. Engels sharply opposed the attempts to bring the teachings of Karl Marx on the social development of "economic materialism", "economic determinism." Economic basis - the basis of social organization, but not systemforming factor eYe with grave improvement.

Society - system of human relationships that take place in the dynamics of economic activity. Activities - social life means people. Activities necessitating different kinds of relationships - the way of manifestation and human development. Relationships are designed to ensure that human development. About the fact that the form of property to be changed at the end of the XX century did not speak only dumb, but that relationship, born ownership, pulled by a distribution of the manufactured product, or its cash equivalent, that the exchange can not fully trust the market, control functions need to be kept by the state converted democratically, that perversely bureaucratic form of government is a generator of corruption, tried to keep silent, knowing the sensitivity of property reform.

Most people have no relevance as to who the owner is, not everyone wants to try on the role of the owner - to turn, to spin, to fight, to risk. Distribution on the contrary, applies to all, and the poor and the nonpoor.

The most difficult part of the economic reforms - to achieve satisfaction in society national product distribution. From this meeting, rather than the form of ownership depends on the health of society. And we come to an important conclusion - the quality of the reform is estimated not by the changes, and the ability to make social life stability characteristics.

In the seventy years of Soviet history were isolated cases, when the management of the economy turned out to random people. They could be just coincidence, confirming its exclusivity, the personnel capacity of the political paradigm. Taking into account the economic disadvantages of excessive centralization in the management of the economy, can afford the following thesis - socialist economies of the Soviet type was not rationally constructed, but it contained a substantial reserve, which gave an opportunity to the new revolutionaries did not repeat the old Bolshevik techniques - to help one and rob others.

The Bolsheviks in the image of the revolutionaries look for all the odious policy of nationalization of property in a more favorable light in comparison with those in the 1990 squandered a national treasure and are extremely reluctant to change their interested attitude to what is happening today. The outcome of the revolution of 1917 was the industrialization and the rise of light industry, crafts, the result of the counter-revolution - 25-year-old depressed economy, the struggle for survival of the textile, shoe, garment production, the decline in the organization of training of qualified personnel across the spectrum - from workers to engineering specialties. In such circumstances, it is time to withdraw from the abstract political ideals demreformators and came to develop a "road map" revival of light industry in the hope that the crisis highlights the urgency of reasonableness "brainstorming" as opposed to "New Economic School" in the trend. What is the road "map" appears to be based on the historical experience of the XX century, when there were all major events [5].

1. The priority of sustainability must be the interests of national advancement. On the development of a very, I would say, but it is on a national scale is not to get. We need to "lick their wounds". At present, the most economically optimistic estimate is in pursuit of a sustainable stabilization of the economic indicators. Doctors in a similar situation are encouraging. Condition "serious but stable" Unfortunately, the economy can not be entered in the "artificial coma" to help overcome the 


\begin{tabular}{|c|c|c|c|c|c|c|}
\hline \multirow{4}{*}{ Impact Factor: } & ISRA (India) & $=3.117$ & SIS (USA) & $=0.912$ & ICV (Poland) & $=6.630$ \\
\hline & ISI (Dubai, UAI & $=0.829$ & РИНЦ (Russia & $=0.156$ & PIF (India) & $=1.940$ \\
\hline & GIF (Australia) & $=0.564$ & ESJI (KZ) & $=8.716$ & IBI (India) & $=4.260$ \\
\hline & JIF & $=1.500$ & SJIF (Morocce & $=5.667$ & OAJI (USA) & $=0.350$ \\
\hline
\end{tabular}

crisis through a more economical expenditure of vitality. We are the first point of the "road map" that's what interested. Doctors seek to mobilize the potential of the life of the body, help to reveal the stock will to live. Our economy is able to fight for survival, there are many smart, knowledgeable, dedicated patriots, however, every year lost their number decreases. According to Doctor of Economics, professor of NRU "Higher School of Economics" V. Inozemtsev - one of the regular contributors AIF, annual leave from the country about 400 thousand people.. Naturally, not all on permanent, someone working on a contract, in search of temporary work. In the first place to help people energetic, light them the green light at the end of the tunnel. Rely on the established officials in a quarter-century type of confidence that is not the sword of justice hanging over them, and a safe senior bureaucrat to receive compensation, it is not necessary. Option - ONF. President and regularly communicates with its interested activists. Communicating efficiently. in search of temporary work. In the first place to help people energetic, light them the green light at the end of the tunnel. Rely on the established officials in a quarter-century type of confidence that is not the sword of justice hanging over them, and a safe senior bureaucrat to receive compensation, it is not necessary. Option - ONF. President and regularly communicates with its interested activists. Communicating efficiently. in search of temporary work. In the first place to help people energetic, light them the green light at the end of the tunnel. Rely on the established officials in a quarter-century type of confidence that is not the sword of justice hanging over them, and a safe senior bureaucrat to receive compensation, it is not necessary. Option - ONF. President and regularly communicates with its interested activists. Communicating efficiently.

Academician AG Aghanbegyan testified that a year of economic recession because of unwise management requires a lot more time to revive the economy. Act on the opening segment should so have the strength to finish and would have left them for the next stage. We should not hope for great achievements. Miraculous transformations can be expected in the private sector. Here it is able to manifest itself in case. In general, the process of the case is insignificant role. Refuse to believe in luck, however, is unwise. It is believed that "lucky" those who are lucky. Successful alignment may induce through professional activity, nature, faith in a favorable outcome, and even in a higher justice. Faith that accompanies the mind, yet no one prevented in an effort to do a good deed.

2. Bet on the full support light industry, like most areas of investment of public funds (financial, legal, political, and humanitarian), contains a risk, but within acceptable values. History checked and Russia as an independent state, and in the USSR in the ability to create a variety of quality goods in demand in sufficient quantity. Strengths of the domestic products of light industry: quality material, hygienic, ergonomic compliance with national and climatic conditions, variety of assortment. In the 1980 s, with the development of co-operation have been positive developments in relation to the design. Clothing and shoes, since 1930, made available to all groups of the population.

In Russia it is possible to produce almost all kinds of materials needed for the light industry. Production of certain types of raw materials limited by volume, in principle, governed by scientific and technical progress. The development of science and technology complement the natural materials artificial synthetic. The country has developed scientific schools in the framework of agricultural production and light industry, the system of specialized vocational training was created. Personnel are trained in schools, colleges, high schools, some schools disappeared in the course of democratic reforms, but the experience was training. It is not difficult to revive. Preserved industrial centers and enterprises. Precisely in those areas where a high percentage of the unemployed. The revival of the enterprises of light industry will lead to increased social and cultural environment and regional traditions, faith in the future the population. Return of social optimism in people.

In favor of focus to develop the production of goods required to meet the physiological needs of man, and are the size of the consumer market. They guarantee the stability of the production orders workload of the relevant goods. 3 . There is still a high creative potential of specialists. $\mathrm{He}$ is quite competitive. Local artists, designers, engineers, and organizers have a high international rating. Often they are bigger and better known abroad than in his native country. Like all creative minded people they are seeking to diversify production development, taking into account the specifics of the market, aware of the importance of monitoring the interest and the mass market opportunities. We've gone from state regulation of the quantity, quality, price of products, than quickly took advantage of random people in the industry. Those who, privatized enterprises, understand it as a way to improve personal incomes and sought to squeeze the maximum margin guilty in the collapse of the industry no less than their "senior" partner was determined by the fate of reforms mediocre people to create an economy. The oligarchs and crony capitalism as historically developing phenomenon. It is a mistake to reject the socially positive sense of their existence. One thing to financiers tycoons, media magnates, oligarchs who made a fortune on speculation mediation wild carbon extraction of raw materials, the other - those who developed the real production with a substantial proportion of the value added, ie, I am thinking about the future. determined using the mediocre fate of the 


\begin{tabular}{|c|c|c|c|c|c|c|}
\hline \multirow{4}{*}{ Impact Factor: } & ISRA (India) & $=3.117$ & SIS (USA) & $=0.912$ & ICV (Poland) & $=6.630$ \\
\hline & ISI (Dubai, UAI & $=0.829$ & РИНЦ (Russia & $=0.156$ & PIF (India) & $=1.940$ \\
\hline & GIF (Australia) & $=0.564$ & ESJI (KZ) & $=8.716$ & IBI (India) & $=4.260$ \\
\hline & JIF & $=1.500$ & SJIF (Morocce & $=5.667$ & OAJI (USA) & $=0.350$ \\
\hline
\end{tabular}

reforms established by the people's economy. The oligarchs and crony capitalism as historically developing phenomenon. It is a mistake to reject the socially positive sense of their existence. One thing to financiers tycoons, media magnates, oligarchs who made a fortune on speculation mediation wild carbon extraction of raw materials, the other - those who developed the real production with a substantial proportion of the value added, ie, I am thinking about the future. determined using the mediocre fate of the reforms established by the people's economy. The oligarchs and crony capitalism as historically developing phenomenon. It is a mistake to reject the socially positive sense of their existence. One thing to financiers tycoons, media magnates, oligarchs who made a fortune on speculation mediation wild carbon extraction of raw materials, the other - those who developed the real production with a substantial proportion of the value added, ie, I am thinking about the future. who developed a real production with a substantial proportion of the value added, ie, I am thinking about the future. who developed a real production with a substantial proportion of the value added, ie, I am thinking about the future.

After the "Gaidar Economic Forum 'and Industrialists Congress (2016), the oligarch Oleg Deripaska spoke very politically mature," 2016 - the last year, when the state is able to use the reserves to help the production, next year we should start to help the state. "We are sure that the opinion of one of the most active and experienced local oligarchs its exclusive look at the interaction between the state and businesses.

To flee from Russia in calculating the future - the lot of those who are opposed to Russia, hiding in the "white fluffy fur" abstract democratic idea of the unity of the world with his greed. The West does not need them, there is demand for their finances - not as impressive by Western standards, both in the looting of the homeland, and "anti-Putin views."

Russian history is rich in examples of intelligent, patriotic economic policy, namely large owners, were ahead of the actions of the public administration, endowed with political responsibility for the professional development of production. It seems that those who are directly responsible for the financial and industrial policy by examining historical experience, waiting to push the production itself "locomotives" for the promotion of existing staff. G. Gref, Sberbank released in the heads of the said government sector, openly referred to "the Gaidar Forum" told about the need for an active government policy planning for overcoming the crisis in the economy, finance investment in real production, control the use of state loans by banks. Frightened by the "wrong" - not cyclical crisis, banks do not want to risk even a "short" loans in the interests of production. They have a "roof" of speculators in the market and themselves became full speculators, floating financial turnover of state loans, leaving the manufacturing enterprises with no credit or assigning them to death for calculating rates.

Light industry enterprises in a similar situation a little bit easier to operate. First, replacement of the equipment is not as costly affair. For example: the basic equipment with modern equipment Physical Laboratory costs \$ 5 million.. Secondly, you can do "short" money that the joint interests of the financier and producer. But at the same time, light industry enterprises more dependent on rapidly changing market conditions, therefore, need to be able to spin quickly, to be able to use centrifugal forces - to diversify production. "Diversification" - the versatile word. In dictionaries allocate 4-5 values. In the context of our study are relevant three: "Diversification of production" as the spread of economic activities to new areas, the branching of production, diversification of products; kind of marketing strategy,

Diversification is currently "working" in the "most favored nation" mode, of course, if you have a creative approach, weighted risks and skillfully the aligned monitoring. We have in mind to begin the transition to the development of mass production from the first type in the second - «lean production», which can be translated as "gentle" or "prudent production". [5]

This type of production fundamentally changes the very purpose of the production process. In this case, the traditional task of manufacturing a large number of similar products to meet the requirements of normative documents, of which the consumer should choose the most suitable for him, replaced by the problem of manufacturing such a product is what you need to present to the consumer and it is in the required amount and at a certain time.

A new type of mass production shifts planning optimization studies to study the peculiarities of the market demand as the total expression of individually different wishes. The market is personified as a function of a large number of parameters involved, which requires strengthening the diversification of production. Changing nature of the market, and employers are required for this transformation adequately and to respond quickly.

It is necessary to take into account the fact that China's growth will inevitably lead to an increase in wage costs. It will emphasize the relevance of logistics calculations. As a result, the Chinese will lose economic attractiveness, and with them it will be possible to compete in the segment, interested Titov. The Russian industrialists there is such a trump card, as its raw materials of natural origin. We hope that the promised investment in agricultural production will reach the farms and fields.

The market for light industry grows at the expense of social and cultural progress, in particular through the development of professional sports, the 


\begin{tabular}{|c|c|c|c|c|c|c|}
\hline \multirow{4}{*}{ Impact Factor: } & ISRA (India) & $=3.117$ & SIS (USA) & $=0.912$ & ICV (Poland) & $=6.630$ \\
\hline & ISI (Dubai, UAE & $=0.829$ & РИНЦ (Russia & $=0.156$ & PIF (India) & $=1.940$ \\
\hline & GIF (Australia) & $=0.564$ & ESJI (KZ) & $=8.716$ & IBI (India) & $=4.260$ \\
\hline & JIF & $=1.500$ & SJIF (Morocce & $=5.667$ & OAJI (USA) & $=0.350$ \\
\hline
\end{tabular}

increase demand for those who choose the sport as a way to a healthy lifestyle. At the end of 2015, "Sport Express" newspaper published an interview with the chairman of the Russian Outdoor Group A. Grebtsova. "The market for outdoor-goods serves climbing, hiking, extreme sports, special forces, rescue teams, service and polar forces. This direction, which require a heavy-duty, freezeproof, waterproof equipment that meets the new international safety and comfort standards. " A. Rowing reported interesting details, in particular, he compared the technological base of production of quality products in the Russian Federation, Europe and Asia. We are "somewhat behind" in his estimation, from the Asian potential, but with Europe "we can accurately compete ... in Russia there are about 30 (!) of companies that are good at sewing." After the ban of imports for state procurement and defense contracts share materials from member countries of the Customs Union, delivered to law enforcement agencies of the country increased from 30\% in 2011 to $83 \%$ in 2018. In 2019 the trend of increasing the share of countries in the production of materials KPES used for the production of ware property should be around $85-90 \%$. Reversal of state order in the direction of domestic production opens possibilities for allied chemical industry (raw yarn, fittings, membranes, insulation). Grow production fabric, tailoring, it will pull the development of equipment. A. Grebnev believes that in order to consolidate the results achieved it is important to: but with Europe "Just we can compete ... there are about 30 (!) of the companies in Russia, who are good at sewing." After the ban of imports for state procurement and defense contracts share materials from member countries of the Customs Union, delivered to law enforcement agencies of the country increased from $30 \%$ in 2011 to $83 \%$ in 2018. In 2019 the trend of increasing the share of countries in the production of materials KPES used for the production of ware property should be around $85-90 \%$. Reversal of state order in the direction of domestic production opens possibilities for allied chemical industry (raw yarn, fittings, membranes, insulation). Grow production fabric, tailoring, it will pull the development of equipment. A. Grebnev believes that in order to consolidate the results achieved it is important to: but with Europe "Just we can compete ... there are about 30 (!) of the companies in Russia, who are good at sewing." After the ban of imports for state procurement and defense contracts share materials from member countries of the Customs Union, delivered to law enforcement agencies of the country increased from $30 \%$ in 2011 to $83 \%$ in 2018. In 2019 the trend of increasing the share of countries in the production of materials KPES used for the production of ware property should be around $85-90 \%$. Reversal of state order in the direction of domestic production opens possibilities for allied chemical industry (raw yarn, fittings, membranes, insulation). Grow production fabric, tailoring, it will pull the development of equipment. A. Grebnev believes that in order to consolidate the results achieved it is important to: who are good at sewing. " After the ban of imports for state procurement and defense contracts share materials from member countries of the Customs Union, delivered to law enforcement agencies of the country increased from $30 \%$ in 2011 to $83 \%$ in 2018 . In 2019 the trend of increasing the share of countries in the production of materials KPES used for the production of ware property should be around $85-90 \%$. Reversal of state order in the direction of domestic production opens possibilities for allied chemical industry (raw yarn, fittings, membranes, insulation). Grow production fabric, tailoring, it will pull the development of equipment. A. Grebnev believes that in order to consolidate the results achieved it is important to: who are good at sewing. "After the ban of imports for state procurement and defense contracts share materials from member countries of the Customs Union, delivered to law enforcement agencies of the country increased from $30 \%$ in 2011 to $83 \%$ in 2018. In 2019 the trend of increasing the share of countries in the production of materials KPES used for the production of ware property should be around $85-90 \%$. Reversal of state order in the direction of domestic production opens possibilities for allied chemical industry (raw yarn, fittings, membranes, insulation). Grow production fabric, tailoring, it will pull the development of equipment. A. Grebnev believes that in order to consolidate the results achieved it is important to: delivered to law enforcement agencies of the country increased from $30 \%$ in 2011 to $83 \%$ in 2018. In 2019 the trend of increasing the share of countries in the production of materials KPES used for the production of ware property should be around 85$90 \%$. Reversal of state order in the direction of domestic production opens possibilities for allied chemical industry (raw yarn, fittings, membranes, insulation). Grow production fabric, tailoring, it will pull the development of equipment. A. Grebnev believes that in order to consolidate the results achieved it is important to: delivered to law enforcement agencies of the country increased from $30 \%$ in 2011 to $83 \%$ in 2018. In 2019 the trend of increasing the share of countries in the production of materials KPES used for the production of ware property should be around $85-90 \%$. Reversal of state order in the direction of domestic production opens possibilities for allied chemical industry (raw yarn, fittings, membranes, insulation). Grow production fabric, tailoring, it will pull the development of equipment. A. Grebnev believes that in order to consolidate the results achieved it is important to: Reversal of state order in the direction of domestic production opens possibilities for allied chemical industry (raw yarn, fittings, membranes, insulation). Grow production fabric, tailoring, it will pull the 


\begin{tabular}{|c|c|c|c|c|c|c|}
\hline \multirow{4}{*}{ Impact Factor: } & ISRA (India) & $=3.117$ & SIS (USA) & $=0.912$ & ICV (Poland) & $=6.630$ \\
\hline & ISI (Dubai, UAI & $=0.829$ & РИНЦ (Russia & $=0.156$ & PIF (India) & $=1.940$ \\
\hline & GIF (Australia) & $=0.564$ & ESJI (KZ) & $=8.716$ & IBI (India) & $=4.260$ \\
\hline & JIF & $=1.500$ & SJIF (Morocco & $=5.667$ & OAJI (USA) & $=0.350$ \\
\hline
\end{tabular}

development of equipment. A. Grebnev believes that in order to consolidate the results achieved it is important to: Reversal of state order in the direction of domestic production opens possibilities for allied chemical industry (raw yarn, fittings, membranes, insulation). Grow production fabric, tailoring, it will pull the development of equipment. A. Grebnev believes that in order to consolidate the results achieved it is important to:

make clear the importance of large retail chains purchase and placement of goods produced in Russia, of course, in view of their good quality;

place the first orders for the production of those "who have stood up and knows how to sew." They have proved their worth;

assist companies to obtain a European certification materials, otherwise they are not interested in foreign companies, and the goods produced in our country, does not get to the West;

actively support the company's collective stands at international exhibitions;

$\checkmark$ represent such enterprises subsidies on loans for the purchase of raw materials. These loans Ratio of total lending should be from 50 to $85 \%$;

$\checkmark$ liberate modern imported equipment from import duties and VAT. Equipment used in sewing shops, $90 \%$ of imports;

$\square$ introduce preferential leasing.

As can be seen, the program A. Grebneva organizes basic and the primary steps in the direction of the light industry to ensure that the return to its former value. However, Heraclitus was right in saying that you can not step twice into the same river. The rise of light industry should be made to the new technological, economic and legal framework.

4. The reforms of the 1990s opened the "floodgates" for the flood of Chinese consumer goods. Purchasing power somehow got out before its price. Shuttles trampled on the border with its eastern neighbor entire prospectus, and in fact with them and through them to form cultural perception of the product. First they bought from despair, then, because it is cheap. And instilled a primitive flavor, bordering on bad taste. In modern times, you need to thoroughly work on the culture of consumer demand - to educate the customer. We have repeatedly emphasized in our publications, understanding that the quality of the natural and artificial phenomena is not the same. Consumer goods are made by man and for man. It alienated human essence, including the socio-cultural status of the individual. Consequently, and an understanding of quality should include a subjective perception of a product's performance through the senses and reflection. quality perception should not be allowed to "drift" to give a sensual element or simplistic thinking. It is important to learn not only the art of modern design, high-quality stitching shoes, clothes, you need to help the consumer to understand all this, send it to the aesthetic and hygienic presentation, make him empathize, to feel the satisfaction of the purchased goods.

Wise Buddha is laid in the eightfold path four key steps: a proper understanding; making the right decisions; finding the right words and, finally, the right of action aimed at implementing the right solutions. The fate of the light industry now depends on what will be the final step. His performance functions of government. Political paradigm is extremely simple - we should not compete with anyone in the fight for the world market, especially the Chinese. The Chinese rightly want to put on and to put the whole world. fifth of the world's population lives in China. Our task is quite different. We need to make sure that the Chinese are not shoes and wore us. Translate purchasing demand for its own Russian production, interest in goods produced in the country. The task such, we are quite capable, as they say manufacturers.

Essential for good governance and the establishment of good relations in the organization are the three. placement type: job satisfaction; enthusiasm for work; commitment to the organization. The extent to which workers have developed these arrangements, essentially determines the results of their work, absenteeism, employee turnover, etc.

Job satisfaction has a very strong influence on human feelings towards the work, so it can be attributed more to the impact of components. Job satisfaction depends on many factors, both internal and external to the person.

However, when a large variety of different factors, and orientation of their effects on human allocated eight working characteristics, from which job satisfaction depends quite stable: [6]

- - the nature and content of the work;

- - the volume of work performed;

- - state of the working space and its surroundings (noise, lighting, comfort, air temperature, etc.)

- - co-workers;

- - leadership (heads, style of leadership, participation in management);

- - payment for work (all forms of payment);

- - promotion opportunities at work;

- - routine, rules of conduct, etc.

Stably great effect on job satisfaction increase has nature and content of the work. Therefore, we consider in more detail the influence of the individual components of this factor.

Long time of standardization and specialization of work were considered and in practice is very strong sources of increasing productivity at work. The higher the standardization and specialization, the higher the performance of the work. However, the relationship between satisfaction with it, and its standardization and specialization is of a different character. If the work is not completely standardized, the job 


\begin{tabular}{|c|c|c|c|c|c|c|}
\hline \multirow{4}{*}{ Impact Factor: } & ISRA (India) & $=3.117$ & SIS (USA) & $=0.912$ & ICV (Poland) & $=6.630$ \\
\hline & ISI (Dubai, UAI & $=0.829$ & РИНЦ (Russia & $=0.156$ & PIF (India) & $=1.940$ \\
\hline & GIF (Australia) & $=0.564$ & ESJI (KZ) & $=8.716$ & IBI (India) & $=4.260$ \\
\hline & JIF & $=1.500$ & SJIF (Morocco & $=5.667$ & OAJI (USA) & $=0.350$ \\
\hline
\end{tabular}

satisfaction is low. With increasing specialization and standardization it begins to grow, but to a certain point, after which it begins to decline rapidly. With the full standardization of satisfaction drops to as low a level as if the work was not completely standardized. Therefore, management should think about how to reduce the negative impact on satisfaction, performance, generated by excessive specialization and standardization. The two most common ways of implementation are rotated (worker movement from one workstation to another) and the expansion work responsibilities to the employee by raising additional tasks.

Commitment to the organization is positioned substantially wider than the passion for work, or job satisfaction. In modern conditions, when more and more organizations are trying to look at the person, not as an employee performing a specific job, but as a member of the organization, striving together with the rest of its members lead the organization to achieve the goals, the importance of this location becomes extremely high. Commitment to the organization is made up of the following components. Firstly, the organization shares the member makes their own goals of the organization and its values. Second, the organization strives to remain a member of the organization and maintains this aspiration even when it may be disadvantageous for him. Third, the organization member is ready not only to try to organize,

Commitment to the organization - the personal characteristics of each individual. However, this does not mean that management can not develop or strengthen this location. There are a number of techniques to facilitate this. And the most successful modern is very much a control system based on the fact that they are developing the employees a strong commitment to the organization and achieve thanks to a very great success. Values as well as the location, have a strong influence on the preferences of the person, on its decisions and behavior in the team. However, between the values and the location is a huge difference. If the latter determine the relationship of man to the object on the principle of "like - not like", "like - not like" and always refer to any particular object, the value set on the basis of human preference "is acceptable - unacceptable", "good bad", "useful - harmful", etc. In this case, values are rather abstract and general in nature, live an "independent" life, regardless of the particular person, formulated in the form of the commandments, statements, wisdom, common standards and can be separated by large groups of people. Therefore, if the location is always highly personalized, the bearers of values are a group of people (for example, values of the middle class), and every single person takes a certain set of values, which he might be changed, but that it should be at any given point in time. formulated in the form of the commandments, statements, wisdom, common standards and can be separated by large groups of people. Therefore, if the location is always highly personalized, the bearers of values are a group of people (for example, values of the middle class), and every single person takes a certain set of values, which he might be changed, but that it should be at any given point in time. formulated in the form of the commandments, statements, wisdom, common standards and can be separated by large groups of people. Therefore, if the location is always highly personalized, the bearers of values are a group of people (for example, values of the middle class), and every single person takes a certain set of values, which he might be changed, but that it should be at any given point in time.

Values can be defined as a set of standards and criteria that a person must be in their lives. This is manifested in the fact that by appropriate assessment taking place around the phenomena, processes and people person decides and carries out its activities.

Values are at the core of human personality. They are fairly stable over time, and not so much. Typically, values are considered as a normative moral base and foundation of human behavior. Values are of two types:

- values related to the purpose of life, the desired results, the outcome of the action, etc .;

- the value relating to the means used by man to achieve the objectives.

The first type includes values, such as values relating to the comforts of life, beauty, peace, equality, freedom, justice, satisfaction, self-esteem, social acceptance, friendship, etc.

The second type of values are the values on ambition, openness, honesty, kindness, intelligence, commitment, responsibility, self-control, etc.

A set of values, which should be a man of his value system, in which the surrounding judged that he is as a person.

Valuable human system is formed mainly in the course of his education. Many people value gets under the influence of parents and other people close to him. Strongly influenced by the education system, religion, literature, cinema, etc.

Value system is subject to development and change, even into adulthood. Important role in this played by the organizational environment. For organizations that are seriously thinking about the harmony of human values and organization values, on the combination of these two systems of values given serious consideration. In particular, much work is done by clearly articulating, explaining and bringing to all members of the organization of the system of values, which should be an organization. Considerable attention is also paid to and clarification of what value orientations are members of the organization

All people in something similar to each other. And it allows us to speak of man in general, talk about its features, especially the behavior, etc. However, no 


\begin{tabular}{|c|c|c|c|c|c|c|}
\hline \multirow{4}{*}{ Impact Factor: } & ISRA (India) & $=3.117$ & SIS (USA) & $=0.912$ & ICV (Poland) & $=6.630$ \\
\hline & ISI (Dubai, UAI & $=0.829$ & РИНЦ (Russia & $=0.156$ & PIF (India) & $=1.940$ \\
\hline & GIF (Australia) & $=0.564$ & ESJI (KZ) & $=8.716$ & IBI (India) & $=4.260$ \\
\hline & JIF & $=1.500$ & SJIF (Morocco & $=5.667$ & OAJI (USA) & $=0.350$ \\
\hline
\end{tabular}

single man is an impersonal "man in general". Each brings something that makes it unique, exclusive, ie, person has a personality. Such a person enters the organization, such a person performs a specific job and plays a role in the organization, it is the kind of person you want to manage, helping him to discover and exploit their potential in solving the tasks of the organization, creating the conditions necessary for its success, the interaction with the organizational environment and solve their own problems in life.

Individuality man consists of three began. First, each person in something similar to everyone else. Secondly, every person in something the same with some other individuals. And finally, thirdly, everyone in something does not look like anyone else. Depending on how the combination of these "principles" of reinforced concrete individuality of each person. At the same time, no matter how built this combination, we must always remember that people are always at the same time has to do with the rest, and is not like the others.

Each person has a stable set of features and characteristics that determine his actions and behavior. These characteristics manifest themselves in a fairly long period of time, so you can feel secure and individuality.

A particular person is fixed on the environment of his personality as individuality has a certain stability, people know each other and keep a certain relation to each other. At the same time it should be noted that under the influence of experience, communicate with others, education and training there is a change of human individuality, sometimes very significant. individuality is influenced by three groups of factors.

The first group consists of heredity and physiological characteristics of a person. Heredity preserves and transmits the external features of the person. But not only. Studies conducted with twins, suggest that genetics may carry and transfer of certain behavioral traits. Human Physiology suggests that a lot in common determines their behavior in humans. In particular, it is the same for all the general adaptation syndrome, reflecting the physiological response to the stimulation.

The second group of factors that shape human personality, constitute factors arising from man's environment. In general, the effect of these factors can be considered as an influence on the formation surrounding the individual. Firstly, a strong effect on the human individual has a culture in which it is formed. Man receives from society norms of behavior, learns under the influence of certain cultural values and beliefs. Second, the human personality is strongly determined by the family in which he grew up. In the family, children learn certain behavioral patterns, produced by their attitudes, attitude to work, the people, their responsibilities, etc. Third, it has a strong influence belonging to certain groups of organizations on human individuality, The man produced a definite identification that specifies a certain type of individual to him, to which he himself embodies and sustainable forms of behavior and, in particular, respond to the impact from the environment. Fourth, the formation of personality is influenced by life experience, individual circumstances, random events, etc. Sometimes it is this group of factors can lead to significant changes in human personality.

The third group of factors that influence the formation of individuality constitute features and characteristics of human nature, its individuality. That is, in this case the situation with the formation of personality as follows: personality affects their own formation and development. This is due to the fact that a person has an active role in their own development and is not exclusively a product of heredity and environment. With all the depth of the human personality and its diversity, you can identify some areas of its characteristics, which can be described as personality. There are people who prefer to keep their distance from others, and this has a significant impact on their behavior in the team. People with authoritarian character believe that there must be order and the difference in the status and position of people, seeking to establish a hierarchy of relationships and the use of force in decision-making and management, readily recognize and appreciate the power of conservative values. Love and faith in people as an individual trait have a strong impact on human interaction with others. This is particularly evident in the willingness to participate in group activities, to promote the development of contacts, interaction and mutual support.

Sensitivity to other people is manifested in the ability of people to empathize with others, take to their heart problems, the ability to put yourself in the place of another, etc. People with these personality traits are well accepted in the community and seek to communicate with people.

Stability in human behavior plays an important role in its relationship with the environment. If a person is stable, responsible and generally predictable, then environment perceive it positively. If, however, he is constantly unbalanced, capricious and unpredictable steps tend to do, the team reacts negatively to such a person.

Self-assessment, ie the way people look at their behavior, capabilities, capabilities, appearance and the like, has a profound effect on human behavior. People with higher self-esteem usually achieve more in life, as they set themselves higher goals and strive to solve more complex problems. At the same time, people with low self-esteem often put themselves in a dependent position and easily submit to people with higher self-esteem.

The perception of risk is an important behavioral characteristic, clearly reflecting the individuality of the person. People who are inclined to risk, less time 


\begin{tabular}{|c|c|c|c|c|c|c|}
\hline \multirow{4}{*}{ Impact Factor: } & ISRA (India) & $=3.117$ & SIS (USA) & $=0.912$ & ICV (Poland) & $=6.630$ \\
\hline & ISI (Dubai, UAI & $=0.829$ & РИНЦ (Russia & $=0.156$ & PIF (India) & $=1.940$ \\
\hline & GIF (Australia) & $=0.564$ & ESJI (KZ) & $=8.716$ & IBI (India) & $=4.260$ \\
\hline & JIF & $=1.500$ & SJIF (Morocce & $=5.667$ & OAJI (USA) & $=0.350$ \\
\hline
\end{tabular}

is spent making decisions and are ready to make decisions with less information. In this case, the result of the decision is not necessarily worse than those who meticulously prepares the solution and collect all the necessary information.

Dogmatism is usually a trait of individuals with limited sight. Dogmatists see the environment as the concentration of risks, refer to the authorities as absolutes and perceive people according to how they relate to the dogmas and absolute authority. Usually dogmatists are people with authoritarian traits. The dogmatists do not tend to look for a large amount of information, quick enough in the decision, but at the same time demonstrate a very high level of confidence in the accuracy and correctness of decisions. It is noted that the dogma prefer to work in a wellstructured groups, regardless of what position they occupy in the group. It was also noted that the dogma poorly aware of how they spend their time during the work, and the fact that they are poorly cope with the administrative work.

The complexity of understanding the phenomena as a characteristic of human individuality reflects its ability to decompose knowable phenomenon into parts and to integrate, synthesize general ideas or opinions about the conscious phenomenon. People with a high awareness of the complexity of showing great ability to process information, consider increasing the number of options and take a more comprehensive solutions than people with low complexity awareness. It is noted that the leaders of the high complexity of understanding in situations with a wide variety of environments better able to cope with their responsibilities, that this type of managers is more prone to extensive contacts with people than the leaders of low-complexity awareness, as well as the fact that these leaders tend to use a variety of resources to solve problems.

The sphere of control reflects the way an individual looks at the source of the factors determining its validity. If a person believes that his behavior depends upon himself, in this case characterized by the presence of the internal sphere of control (introverts) for him. If he believes that all depends on the case, external circumstances, actions of other people, it is considered that it has an outer sphere of control (extroverts). Introverts better control their actions are more focused on achieving results, more active, more satisfied with their jobs. They enjoy an informal management style, they like to influence others, but do not like to work on myself, like to hold managerial positions. Extroverts, on the contrary, prefer the formal structure prefer to work under the policy guidance. If they hold managerial positions,

There are a large number of tests and other tools to determine the characteristics of individuality. In modern management these issues, and this type of activity is given a lot of attention. And this is due primarily to the fact that the organization's success depends on how well it can use all the means at its disposal in the human potential.

Human behavior, his actions make a definite contribution to the life of the group.

There is no canonized definition of a small group, as it is quite flexible and are exposed to circumstances phenomenon. However, the widely adopted fairly common, well-established view on a small group (hereinafter always the term "group" will be used in this sense) as a relatively separate union of a small number of people (usually not more than ten twenty-five) are in a fairly stable cooperation and implementing joint actions for a sufficiently long period of time. Interaction of group members based on some common interest and may be associated with achieving a common goal. The group has a certain potential for the group or group capabilities that allow it to interact with the environment and adapt to changes in the environment. follows.

The characteristic features of the group are as

Firstly, the group members identify themselves and their actions to the group as a whole and thus in external interactions act as if on behalf of the group. Man does not speak about himself, but about the group as a whole, using the pronoun we, we, our, us and the so-called

Secondly, the interaction between the group members is in the nature of direct contact, personal conversation, observation of the behavior of each other, etc. In the group of people to communicate directly with each other, giving a formal interactions "human" form.

Thirdly, the group, along with the formal distribution of roles, if any, necessarily develops informal roles, usually recognized as a group. Individual members of the group take on the role of generators of ideas, while others tend to coordinate the efforts of team members, and others concerned about the relationship between the group of maintaining a good climate in the team, the fourth track of the fact that there was an order to work, all carried out in time and brought to the end. There are people who perform the role of the Outliner, they set group goals, monitor the effects of the environment at a crucial task group. [6]

These and other roles of group behavior people perform in accordance with their abilities and inner calling. Therefore, in a well-functioning groups are usually created opportunities for a person to behave in accordance with their abilities to group actions and organically inherent in it a particular role in the group.

There are two types of groups: formal and informal. Both of these types of groups are relevant to the organization and have a great influence on the members of the organization.

Formal groups are usually identified as the structural units of the organization. They have a formally designated leader, formally defined roles 


\begin{tabular}{|c|c|c|c|c|c|c|}
\hline \multirow{4}{*}{ Impact Factor: } & ISRA (India) & $=3.117$ & SIS (USA) & $=0.912$ & ICV (Poland) & $=6.630$ \\
\hline & ISI (Dubai, UAI & $=0.829$ & РИНЦ (Russia & $=0.156$ & PIF (India) & $=1.940$ \\
\hline & GIF (Australia) & $=0.564$ & ESJI (KZ) & $=8.716$ & IBI (India) & $=4.260$ \\
\hline & JIF & $=1.500$ & SJIF (Morocco & $=5.667$ & OAJI (USA) & $=0.350$ \\
\hline
\end{tabular}

structure of posts and positions within the group, as well as formally assigned to them the functions and tasks. Formal groups can be formed to perform regular functions, such as accounting, and can be created for a specific target, such as the Commission on the development of a project.

Informal groups are not orders of the leadership and formal regulations, and members of the organization in line so mutual sympathy, common interests, same hobbies, habits, etc. These groups exist in all organizations, although they are not represented in the schemes that reflect the structure of the organization, its structure. Informal groups usually have their own unwritten rules and norms of behavior, people are well aware of who is part of an informal group of them, and who is not, in the informal groups formed a certain distribution of roles and positions. Usually these groups have explicitly or implicitly defined leader. In many cases, informal groups can exert influence on its members, an equal or even greater! The formal structure.

Why am I having a group that causes people to form groups and to join them? These questions are very important for the understanding of human behavior in organizations. It is obvious that the group appear in the organization and functioning as a separate structural unit in connection with the fact that as a result of the division of labor are allocated separate specialized functions, requiring for their execution of a certain set of people with a qualification, having a certain profession and finished in a system of joint activities to perform some work. A similar situation is observed in the formation of groups to resolve targets.

But this is only one side of the appearance of groups in the organization. Usually it leads to the formation of formal groups. Another important reason for the formation of groups is a natural human desire to unite with other people, to the formation of resistant forms of interaction with people. Group gives a person a sense of security, from the group, he is waiting for support, assistance in solving their problems and warnings. In the group the person easier to achieve a "reward" in the form of recognition, praise or material reward, a person learns in a group, learning from the experience of other, better aware of their capabilities and potential. Group gives a person more confidence in external interactions, contributes to its Identity. *

Finally, the group provides a person the opportunity to pass the time in a pleasant environment for him, to avoid loneliness and state of helplessness, worthlessness. Every person aspires to being loved by someone, fit someone belong to someone, and the group can be a source of solutions to these human problems.

* This term reflects human identity, his identification with certain stable phenomenon or condition.
Regardless of the type of the group, in which organization is formed and functions, as well as someone who specifically included in the group may indicate some common elements and factors characterizing construction group, its structure and operation process of the group in its environment.

The life of the group, its functioning is influenced by three factors: the characteristics of the group members; structural group characteristics; situational characteristics.

All of these factors are not only in the interaction, mutual influence, but also experience a strong feedback effect on the part of the functioning of the group as a result of vital activity of the group is changing characteristics of the person, changes the construction of the group and there are changes in its environment.

The characteristics of group members, affecting its functioning, are the personal characteristics of the person, as well as abilities, education and experience. Above we have discussed in detail the personal characteristics

human, so we will not dwell on them in this review. As for the other characteristics, it is noted that a person's ability to perform the work have a great impact on the functioning of the group and to perform its role as a man. Also, a significant impact on the level of the group have

Despite the fundamental differences between these concepts discussed above, they, nevertheless, have something in common in their basis, which reflects a certain commonality in the human motivation to take action.

Called Maslow's concept Alderfera Mack Klellakda, Herzberg lead to the conclusion that there is not any canonized doctrine, explaining what lies at the heart of human motivation and the motivation is determined. Each set forth certain theories have a fundamental difference.

Thus, each theory has something special, distinctive, which gave her the opportunity to be widely recognized scholars and practitioners, and to make a significant contribution to the development of knowledge about motivation. However, despite fundamental differences, all four of the above theories have one thing in common, which allows to establish certain parallels between them. A characteristic feature of all four theories is that they learn the needs and provide the classification requirements, allowing a certain conclusions about the mechanism of human motivation. Comparing the classification of all four theories, it may be noted that the various theories outlined in the group needs sufficiently definite match.

Much depends on the organizational culture and management staff of enterprises of light industry.

Enterprise - is a complex organism, the basis of life potential of which is organizational culture: something for which people have become members of 


\begin{tabular}{|c|c|c|c|c|c|c|}
\hline \multirow{4}{*}{ Impact Factor: } & ISRA (India) & $=3.117$ & SIS (USA) & $=0.912$ & ICV (Poland) & $=6.630$ \\
\hline & ISI (Dubai, UAI & $=0.829$ & РИНЦ (Russia & $=0.156$ & PIF (India) & $=1.940$ \\
\hline & GIF (Australia) & $=0.564$ & ESJI (KZ) & $=8.716$ & IBI (India) & $=4.260$ \\
\hline & JIF & $=1.500$ & SJIF (Morocco & $=5.667$ & OAJI (USA) & $=0.350$ \\
\hline
\end{tabular}

the company; how relationships are built between them; some stable rules and principles of life and activity of the enterprise they share; that, in their opinion, is good and what is bad, and a lot more of what refers to the values and norms. All this not only distinguishes one organization from another, but also greatly determines the success of the operation and survival of the business in the long term. Organizational culture is not so clearly evident on the surface, it is difficult to "feel". If we can say that the company has a "soul", the soul of this is organizational culture.

Bearers of the organizational culture is the people. However, in companies with established organizational culture, they like to be separated from the people and becomes an attribute of the company, its part, has an active effect on the members of the enterprise, modifying their behavior in accordance with the norms and values that make up its foundation.

Since culture plays a very important role in the life of the enterprise, it should be the subject of attention from management. Management not only corresponds to the organizational culture and is strongly dependent on it, but it may in turn have an impact on the formation and development of organizational culture. To do this, managers must be able to analyze organizational culture and its influence on the formation and change in the desired direction.

In modern literature there are both very narrow and very broad interpretation of what constitutes a culture of enterprise.

Most often, the organizational culture is treated as received by most of the company philosophy and management ideology, assumptions, values, beliefs, expectations, location and rules underlying relationships and interactions, both within the enterprise and beyond. [7]

Using a common, that is inherent in most definitions, it is possible to understand the organizational culture as follows. Organizational culture - a set of the most important assumptions adopted by the company staff and receive expression in the claimed value of the company, giving the people guidance of their behavior and actions. These value orientations are transferred to individuals through a "symbolic" means of spiritual and material intraenvironment.

The basic assumption is that which adheres to the staff of the company in their behavior and actions. These assumptions are often associated with a vision of environmental protection of the individual (group, community enterprise, world) and its regulating variables (nature, space, time, work, relationships, and so on. D.). It is often difficult to articulate this vision in relation to the enterprise.

Values (or values orientation) oriented individual in what behavior should be considered acceptable or unacceptable. For example, some companies believed that the "customer is always right", so in them is unacceptable to blame the customer for failure in the enterprise. In the other could be the other way around. However, in fact, and in another case, accepted values help the individual to understand how he should act in a particular situation.

"Symbols" is that by which the value orientation "transferred" collective enterprise. Many businesses have special designed for all the documents in which they describe in detail their value orientation. However, the content and significance of the latest most fully disclosed to employees through the "walking" of history, legends and myths. They tell, retell, interpret. As a result, they sometimes have a greater effect on individuals than those values, which are recorded in the advertising booklet of the enterprise.

Organizational culture has a certain structure. The latter can be viewed as a three-tiered.

First, the "surface" or "symbolic" level. It includes those visible external facts as - applied technology and Architecture, use of space and time, the observed behavior, language, slogans, etc., or anything that you can feel and perceive through the known five senses (see, hear, feel taste and smell, touch). At this level, things and events is easy to detect, but not always possible to decipher and interpret in terms of organizational culture.

Second, "sub-surface" level. At this level, detected values and beliefs shared by the collective enterprise, in accordance with the extent to which these values are reflected in the symbols and language. The perception of values and beliefs is conscious in nature and depends on the willingness of people.

The third "deep" level. It includes basic assumptions that are difficult to understand even by the collective of the enterprise without a special focus on this issue. These hidden and taken for granted assumptions guide the behavior of people, helping them to perceive the attributes that characterize the organizational culture. [7]

Accordingly, to which of said levels being studied, there is a division organization cultures on subjective and objective.

Subjective organizational culture based on the shared employees assumptions samples, belief and expectations, as well as the perception of the group organizational environment with its values, norms and roles that exist outside the individual. These include a number of "symbols" of the elements, especially the "spiritual" side: the heroes of the enterprise, myths, stories about the company and its leaders, organizational taboos, rites and rituals, the perception of the language of communication and slogans. Subjective organizational culture is the basis of formation of administrative culture, ie, leadership styles and solutions leaders of problems and their behavior in general. This creates a difference between similar-looking organizational culture. For example, two businesses can claim a quality service to their 


\begin{tabular}{|c|c|c|c|c|c|c|}
\hline \multirow{4}{*}{ Impact Factor: } & ISRA (India) & $=3.117$ & SIS (USA) & $=0.912$ & ICV (Poland) & $=6.630$ \\
\hline & ISI (Dubai, UAI & $=0.829$ & РИНЦ (Russia & $=0.156$ & PIF (India) & $=1.940$ \\
\hline & GIF (Australia) & $=0.564$ & ESJI (KZ) & $=8.716$ & IBI (India) & $=4.260$ \\
\hline & JIF & $=1.500$ & SJIF (Morocco & $=5.667$ & OAJI (USA) & $=0.350$ \\
\hline
\end{tabular}

customers. But the final outcome will largely depend on the

Objective organizational culture is usually associated with the physical environment, created by the company: the building itself and its design, location, equipment and furniture, the colors and the amount of space, facilities, cafeteria, reception rooms, parking for cars and the cars themselves. All this is more or less reflects the values upheld by the company staff. Although both aspects of organizational culture are important, but the subjective aspect creates more opportunities to find both general and differences between people, and between enterprises.

Specific organizational culture can be considered based on the ten characteristics:

- awareness of themselves and their place in the company (some cultures value their internal concealment employee sentiment, others - encouraged their external manifestation, in some cases, independence and creativity is manifested through cooperation, and in others - through individualism);

- communication system, and the language of communication (using oral, written, non-verbal communication, "telephone justice" and transparency of communication varies from group to group, from enterprise to enterprise, jargon, acronyms, gestures vary depending on the industry, functional and territorial jurisdiction of enterprises);

- appearance, dress and presentation at work (a variety of uniforms and workwear, business style, cleanliness, cosmetics, hair, etc. confirm the presence of many microcultures);

- what and how people eat, habits and traditions in this area (catering workers, including the presence or absence of those places in the enterprise; people bring their own food or visit the coffee shop inside or outside the enterprise, grant power, frequency and duration of power; eat whether workers different levels together or separately, etc.);

- time awareness, attitude and its use (degree of precision and time relativity among workers; temporary compliance regulations and promotion for it; mono or chronic polychronic use time);

- relationships between people (by age and sex, status and power, wisdom and intellect, experience and knowledge, rank and protocol, religion and nationality, etc.; the degree of formalization of relations, support received, the path of conflict resolution);

- value (as a set of guidelines that is good and what is bad) and norms (as a set of assumptions and expectations regarding a certain type of behavior) that people value in their organizational life (its position, titles, or the work itself, etc.), and how these values are stored;

- faith in something and the attitude or disposition to something (a belief in leadership, success in their own strength, in mutual aid, in ethical behavior, fairness, etc.; attitude to colleagues, clients and competitors, to evil and violence, aggression, etc.; the influence of religion and morality);

- the development worker and learning (thoughtless or deliberate execution of the work; rely on intellect or strength; workers reporting procedures, the recognition or denial of the primacy of logic in the reasoning and actions, abstraction and conceptualization in thinking or memorizing; approaches to the explanation of the reasons);

- work ethic and motivation (attitude towards work and responsibility at work, separation and replacement work; cleanliness of the workplace; the quality of work, habits of work, performance evaluation and compensation, the relationship "man machine", individual or group work, promotion at work).

Above the marked characteristics of the enterprise culture, taken together, reflect and give meaning to the concept of organizational culture

Organizational culture is a set of the most important assumptions, values and symbols shared by members of the collective The enterprise was. Identify different levels of organizational culture: surface, subsurface, deeper.

Depending on the prevalence of the elements of a given level of subjective and objective isolated culture The enterprise was collective. The first is the basis of formation of administrative culture and management style.

Organizational culture is not a monolith, and is made up of the dominant culture, subcultures and counter-cultures of groups, strengthen or weaken the culture of the organization as a whole. The strength of the culture depends on the size and the separability of its main attributes of the members of staff of the enterprise, as well as the clarity of its priorities.

Development of organizational culture suggests its formation, maintenance, and modification. Building a culture takes place in a solution now two important issues: the outer - and inner adaptation integration. The formation of culture in the collective enterprise culture affects society / nation, within which the enterprise operates.

Organizational culture is supported by what is paid attention to how estimated and monitored the activities of the members of the collective enterprise, response methods to critical situations - role modeling and training, the criteria of motivation, as well as the criteria in personnel work. Observance of rituals, customs and traditions also helps to maintain the organizational culture.

Changing organizational culture is to a certain extent the opposite effect in relation to its maintenance. Changes in behavior can lead to changes in the culture of the collective enterprise, and vice versa. There are three possible combinations of changes in behavior and culture in the enterprise team: 1) changing the culture without changing the 


\begin{tabular}{|c|c|c|c|c|c|c|}
\hline \multirow{4}{*}{ Impact Factor: } & ISRA (India) & $=3.117$ & SIS (USA) & $=0.912$ & ICV (Poland) & $=6.630$ \\
\hline & ISI (Dubai, UAI & $=0.829$ & РИНЦ (Russia & $=0.156$ & PIF (India) & $=1.940$ \\
\hline & GIF (Australia) & $=0.564$ & ESJI (KZ) & $=8.716$ & IBI (India) & $=4.260$ \\
\hline & JIF & $=1.500$ & SJIF (Morocco & $=5.667$ & OAJI (USA) & $=0.350$ \\
\hline
\end{tabular}

behavior; 2) a change in behavior without changing the culture; 3 ) a change in behavior and culture.

The study of the impact of culture on organizational effectiveness is related to the choice of approaches and variables. Each of the existing models of the impact of culture uses its own set of criteria for the organizational variables; Thus, in this sate V. organizational processes, and Peter Waterman values, T. Parsons - a function of the social system, while Quinn and Rohrbach - a system of competing values.

Success in business requires a high degree of compatibility of the strategy and culture of the collective enterprise. The following situations may arise: is ignored culture, strongly hindering the effective implementation of the chosen strategy; the control system adjusts to the existing collective enterprise culture; attempt to change the culture in accordance with the chosen strategy; strategy adapts to the existing culture.

Great influence of national culture in the organization. In the study of the national settled in organizational culture are two questions: what you need to know about the national culture, to anticipate its impact on the enterprise culture; is it possible to "splice" the best of the different national cultures within a single enterprise staff in order to improve its efficiency?

If the answer to the first question, various models: J. Miller - a systematic approach; G. Hofstida - variables of the national culture; Lane and Distefano - national culture variables and variations in their change, correlated with certain variations of organizational variables. In these purposes can also studied a group of elements that form the state of society: the land, nature and the climate; language, faith, morality and the law; family, education and training; forms of socialization of people's lives; the method of farming, the economy and business; politics, history and form of government. The theory of «Z» Ouchi makes an attempt to answer the second question of the synergy of different cultures. The model uses a comparative analysis of seven organizational variables as they relate to national circumstances, and according to its results the culture of type «Z».

The results of the survey on the impact of marketing communications on the promotion of products of light industry in the markets of SFD and North Caucasus Federal District with the participation of students, teachers and specialists and the evaluation of competence of survey participants using the coefficient of concordance $\mathrm{W}$ showed the same feature, characteristic of a survey of other problems, such as the impact of competitive potential on the competitiveness of and demand for products, the role of the chipping of fur products to improve filling market demand this produ ktsiey, demand and quality, revealed the relationship competitiveness of enterprises and the competitiveness of products for the formation of a stable demand for manufactured by domestic enterprises of light industry products for consumers SFD and North Caucasus Federal District and to provide them with a stable economic situation with a guarantee against bankruptcy regions. In addition, it was carried outYe with graveMr survey to assess the significance of master's training to fill the domestic enterprises of light industry by highly qualified specialists, the need for which is so acute that borders on catastrophe to ensure the industry such specialists capable of against the background of advanced innovative technology solutions to form the innovative production, guaranteeing enterprises manufacture import-substituting products, create town-forming enterprises in small and medium-sized cities of the Russian Federation, of the bespechivaya population of these cities not only in the workplace, which in itself is vital to ensure that the population of these cities social protection, reduction of unemployment and a decrease in population explosions that can destroy the integrity of the country. Besides, elimination of deficit of highly skilled experts, would provide a justification for the producers in these industries for the accumulation of domestic market demand products, including those for children, which is a significant deficit today. Naturally, the need to develop domestic production of components, because of their number for the product is greater than one hundred titles, and will lead not only to create new jobs, but will ensure that it is especially important due to the reduction in manufacturing costs for the successful operation of the light industry enterprises products of light industry to ensure it a competitive edge not only in domestic market but also for export. [8] It would provide justification for manufacturers in such industries for the accumulation of domestic market demand products, including those for children, which is a significant deficit today. Naturally, the need to develop domestic production of components, because of their number for the product is greater than one hundred titles, and will lead not only to create new jobs, but will ensure that it is especially important due to the reduction in manufacturing costs for the successful operation of the light industry enterprises products of light industry to ensure it a competitive edge not only in domestic market but also for export. [8] It would provide justification for manufacturers in such industries for the accumulation of domestic market demand products, including those for children, which is a significant deficit today. Naturally, the need to develop domestic production of components, because of their number for the product is greater than one hundred titles, and will lead not only to create new jobs, but will ensure that it is especially important due to the reduction in manufacturing costs for the successful operation of the light industry enterprises products of light industry to ensure it a competitive 


\begin{tabular}{|c|c|c|c|c|c|c|}
\hline \multirow{4}{*}{ Impact Factor: } & ISRA (India) & $=3.117$ & SIS (USA) & $=0.912$ & ICV (Poland) & $=6.630$ \\
\hline & ISI (Dubai, UAE & $=0.829$ & РИНЦ (Russia & $=0.156$ & PIF (India) & $=1.940$ \\
\hline & GIF (Australia) & $=0.564$ & ESJI (KZ) & $=8.716$ & IBI (India) & $=4.260$ \\
\hline & JIF & $=1.500$ & SJIF (Morocce & $=5.667$ & OAJI (USA) & $=0.350$ \\
\hline
\end{tabular}

edge not only in domestic market but also for export. [8]

Analyzing the results of the survey with the participation of all respondents traced the main concern of the survey participants - uncertainty in the interest of municipal, regional and federal branches of government to provide assistance to solve vital problems typical for light industry enterprises, namely:

- low salary;

- low profitability of manufactured products;

- high staff turnover;

- morally and physically obsolete equipment, ie technical and technological backwardness of light industry from foreign countries, characterized by high consumption of materials, energy content, and laborintensive production;

- a low level of innovative solutions in the industry, provoking weak competitiveness of domestic goods, in the low share of "know-how" and innovative products in the volume of sales in the Russian and global markets;

- a high share of imports that caused the strengthening of the strategic and marketable government dependency on foreign countries, although it is no secret that the competitiveness achieved through the modernization of production processes. The new equipment allows to produce new types of products, but often the equipment we have just imported. We already bought it more than our foreign competitors, moreover, are forced to keep still and backup equipment, as if some unit of broken equipment or fails, it could trigger a stop the whole process, and reduce the output volume, which, of course, have a negative impact on the performance of the enterprise;

- the absence of a civilized market of consumer goods, in terms of increased competition in the domestic market between Russian and foreign producers;

- social and personnel problem, manifested in the shortage of high-skilled professionals, managers, main and auxiliary workers in all production processes.

The occurrence of systemic problems in the industry due to intrasectoral and externally industry reasons. They are connected both with the industry activity, and with the ongoing institutional reforms and changes in the national economy, in the area of legislative and foreign economic policy of the country, as well as changes in the global economy.

This is mainly due to structural imbalances light industry - the disparity in the moment of scale and industry features high quality to meet the growing demand for products, to suspend a critical drop in the share of domestic goods in the internal market and prevent emerging threat to national security losses.
The reasons for the first group of problems technical and technological backwardness of light industry from foreign countries are as follows:

- low capacity installed in the equipment industry, most of which is morally and physically obsolete. The share of equipment in the machine industry park (according to Rosstat), operated by up to 5 years amounted to only 1.2 percent at the beginning of 2017, 6-10 years already 39.6 percent, 11-20 years already 45.4 percent and more than 20 years - 13.8 percent[eight]. Worn-out and obsolete equipment is not only incapable of producing a modern range of high quality products, but creates and poor working conditions leading to increased industrial injuries. As a result of this factor, the specific labor-intensive production in the industry in 3-5 times higher than abroad;

- lack of modern technological processes and automated control systems;

- smaller in comparison with internationally accepted standards, the rate of technological renovation. The coefficient of renewal of equipment at Russian enterprises is 1-2 per cent per year and is carried out through credit and equity in foreign companies, the figure is $16-19$ per cent, largely due to the investment support from their states who are interested in the development of light industry. Low level hardware upgrades results in a reduction of production capacity (due to significant excess output morally and physically worn-out equipment on the introduction of a new one)

Over the last 5 years the production capacity decreased:

- on cotton gray fabric by 14 percent;

- on a linen cloth in the third, and on woolen cloth is almost 4 times;

- on jerseys 1.8 times, hosiery 10 percent;

- on shoes by 62 percent.

- a significant backlog of foreign enterprises in the level of organization of production, in the operational control of the process, in the efficiency of marketing services companies and large 2-2.5 times the duration of orders for manufacturing of products. As a result of these reasons, there is a high dependency of textile companies of raw material quality, coloring agents and textile auxiliaries (TIA) and, as a consequence, high production costs due to the high cost of raw materials, dyes, textile auxiliaries and accessories (a large proportion of which are imported from abroad), and the high cost of energy, whose prices are unreasonably grow super-fast pace; and weak competitiveness in the domestic and European markets for Russian goods compared to imports, both in quality, design and price,

The second group of problems - a low level of innovation and investment activity for the following reasons: 


\begin{tabular}{|c|c|c|c|c|c|c|}
\hline \multirow{4}{*}{ Impact Factor: } & ISRA (India) & $=3.117$ & SIS (USA) & $=0.912$ & ICV (Poland) & $=6.630$ \\
\hline & ISI (Dubai, UAI & $=0.829$ & РИНЦ (Russia & $=0.156$ & PIF (India) & $=1.940$ \\
\hline & GIF (Australia) & $=0.564$ & ESJI (KZ) & $=8.716$ & IBI (India) & $=4.260$ \\
\hline & JIF & $=1.500$ & SJIF (Morocco & $=5.667$ & OAJI (USA) & $=0.350$ \\
\hline
\end{tabular}

- lack of investment needed for the modernization of the industry and the introduction of "breakthrough" innovation and investment projects to remove the structural constraints of the industry and to launch production of a completely new (consumer properties) of products that are in demand on the domestic and foreign markets;

- reduction in the volume and effectiveness of research and development due to lower R \& D budget funding (in 2018 from the budget of the R \& D performed by RUR 25.2 million, in 2019 -.. to 25.0 mln. rub.). The worst affected is fundamental and exploratory research. Many research and development that can make a new technological basis for the industry to expand production of competitive hightech products, have not been brought to completion and require continuing and deepening development[9].

Scientific organizations and are not allocated funds for the development of the experimental base, which reduces the efficiency of scientific research. Leading foreign countries on the development of science and its experimental facilities are investing 69 per cent of the turnover of products, which allows them to consistently achieve high achievements in science, improve the technological level of production and competitiveness of the goods in accordance with the requirements of the global market.

Without taking effective measures to improve the situation in the industry, her condition could reach a critical level.

Especially urgent task of improving the competitiveness of footwear enterprises which, because of external factors (increased competition due to globalization, the global financial crisis) and internal (ineffective management) lost their competitive position in the domestic and foreign markets. In response to negative processes of regionalization processes are amplified in the external environment and create different network structures, one of which is an alliance of producers and the state.

There are three main options for the enterprise concept in a developed economy: neoclassical, agent (shareholder) and the concept of partnership.

The concept of partnership or stakeholder theory, is considered the dependence of firm action against the interests of a wide variety of stakeholders, which include customers, suppliers, shareholders, managers, workers, and others. In addition, each of the partners has a certain right to control over the enterprise, so the concept implies the need to take decisions based on their interests.

Theory of strategic management is one of the most difficult sections of management science. Over a relatively short period of existence, was characterized by the rapid development of a number of concepts, it has succeeded in becoming an independent scientific discipline with its own academic infrastructure. The most important question that must be answered theory is to determine the sources of long-term competitiveness of enterprises. These sources are defined by the Company's strategy and, therefore, raise the question of its nature.

Reliability and versatility - attributes of quality of knowledge. Reliability to minimize risks, flexibility relieves tension with the search for new solutions to the problem - "from the good deed goes unpunished." For quality comes at a price. Board, as is commonly believed, has a financial relationship, but it does not always look right. In the history of civilization, there are two outstanding achievements at the level of revolutions, is clearly not an equivalent assessment, namely:

- price discovery knowledge, comparable to the cost of human things, "knowledge - force";

- awareness of the special significance of theoretical knowledge in the form of concepts and related forms of abstract thought - judgment, reasoning. This naturally led to the need to develop a specific technology of production - methodology knowledge of the essence of relations existing phenomena. The visible part of the world "designed" to the consumer, unseen - on the manufacturer. manufacturers competition can be formalized as a simple technical problem - to get through a lot of chaotic phenomena of the visible part of the world in its hidden part, to understand it, to come back and understand chaos as the order of co-existence and development of the phenomena. Order and there is regularity. Laws exist only in textbooks on their own, separately. In fact, the law - is the stability, the community and the need to order.

Economic science in the XX century came in a difficult situation, which is the end of the century, had become critical. The theory of Adam Smith and Karl Marx method does not fit into the contours of the developed capitalist ideology. In Europe and North America, the very idea of capitalism historicity perceived as heresy. The history of capitalism has a beginning, but the presence of the start can not be the basis of the output of the limbs. Math - an exact science, it allows infinity to one side. The dialectical interpretation of infinity - the metaphysical, abstracted from real history. Rescue of economic science can not be found in the historical and formal-logical sense of reality, that is in mathematical calculus, statistics[four].

For sewing school clothes should be used fabrics from natural fibers such as wool, linen, cotton. These fabrics are most hygienic, have high hygroscopicity and good thermostatic properties. The study of 98 school trousers manufacturers products, only 14 (!) Meet the quality mark that is safe for health according to the requirements. Of the 30 manufacturers of shirts had 28 violations. Hardly anyone from dealing with a state of the domestic light industry, expecting different results. Affects not so much the depressing statistics, how many professional comments 


\begin{tabular}{|c|c|c|c|c|c|c|}
\hline \multirow{4}{*}{ Impact Factor: } & ISRA (India) & $=3.117$ & SIS (USA) & $=0.912$ & ICV (Poland) & $=6.630$ \\
\hline & ISI (Dubai, UAI & $=0.829$ & РИНЦ (Russia & $=0.156$ & PIF (India) & $=1.940$ \\
\hline & GIF (Australia) & $=0.564$ & ESJI (KZ) & $=8.716$ & IBI (India) & $=4.260$ \\
\hline & JIF & $=1.500$ & SJIF (Morocce & $=5.667$ & OAJI (USA) & $=0.350$ \\
\hline
\end{tabular}

addressed consumer products clothing production. Through specialist journalist advises: "If you are not on the label contains the information about the manufacturer - its name and location, the composition of the tissue, release date - it is an occasion to reflect (!)." and I would like to ask the unknown, but the responsibility for the status of the interlocutor reporter: "And the presence of this information can be taken as a guarantee," It is also significant that, judging by the lack of continuing this test, all the subjects of relations were at their interest. Reviewers - reported on the work done in preparation for the AllRussia Day of Knowledge, verifiable, shaking off some awkwardness for something that does not fall into a rut of the national movement for universal holiday, continued to do everything as you did to the reference check and during it. For unscrupulous and irresponsible producers, regardless of what they produce - or the rocket boots, the main thing - it is the triumph of the bureaucracy, which they will always find a sufficiently general so as not to interfere with each other to live the well-known concept.

- the development of modern technologies of production;

- existing high professional culture, the backbone of which factor is the personal form of justice.

Market - an integral part of society. The order of the market reflects the state of society, and the manufacturer focuses on the state of the market. For it is not a barometer of national interest - market opportunities. Market - the driving force of production. If the market culture is really ahead of the production culture, the objections to the consumer approach to production would be reduced to a minimum. In fact, the market culture in Russia laid the manufacturers are not much less than consumers with their lean purse. In our market from the beginning dominated intermediaries and speculators. Under them built and legislation leading to a lot of different interpretations of the action and so many opportunities to avoid criminal liability, that boast Ostap Bender about four hundred ways to get around the CC seems vaudeville humor. Before the onslaught of intermediaries and speculators, often in tuxedos from the famous couturier, traditional Russian woes receded into the background and began to work on the new leaders. Quality management in this situation has become a quality market manipulation in the interests of the owners. Until we rebuild the relationship in the field of exchange of goods for money and not raise consumer purchasing power to the choice of quality products, we have a quality problem will remain at the level of economic theory.

Discussion at AG Aganbegian ended as expected - the majority deem economic training associated with the production characteristics. Only in this way it is possible to provide the necessary level of specificity. The reforms of the 1990s to develop a scheme was canceled, resulted in training of managers we have in accordance with the procedure established by them, whose economy defined as a reference. Incoherence of economic policy did not hide, on the contrary, was praised. Absolutization in science is not admissible as a brake on scientific creativity. However, recognizing the need for the transitional period, which came to power economists teachers take those history books know what needs to be done during the transition. We wanted at the expense of "one-two" to be in the postindustrial economy, the development of industrial minuyu. With all the defects of socialist industrialization, it became an objective historical fact for two five-year and five "five-year" reindustrialization even failed to implement. As a result, we returned to the old logic of development. Engines industrial progress made MIC and Roskosmos, hoping that they will pull to the development of the rest of the industry. But, not being confident in the ability of others to cope with new challenges, for the old and they do not perform, the government called on MIC to deploy production of a range of mass consumer in order to meet the domestic needs of the population. hoping that they will pull to the development of the rest of the industry. But, not being confident in the ability of others to cope with new challenges, for the old and they do not perform, the government called on MIC to deploy production of a range of mass consumer in order to meet the domestic needs of the population. hoping that they will pull to the development of the rest of the industry. But, not being confident in the ability of others to cope with new challenges, for the old and they do not perform, the government called on MIC to deploy production of a range of mass consumer in order to meet the domestic needs of the population.

One of the basic rules of quality management experts believe a return to the original position if the process has not gone. Therefore, the restoration of the previous model of economic growth we need to write in the active power. To this I would have to apply the principle of consistency in the implementation of socialist imperative of the unity of theory and practice. Vippersony Soviet Politburo decisions are not developed. They agree upon and adopt them. Draft decisions prepared by professionals, consultants, "subcontractors" and "initiators", they were scientists, Academy of Sciences of the USSR and most successful production managers. Casual man in the industrial departments Regional Party Committee of the CPSU there could only once Stirlitz. It was arranged party and people's control. Certainly not perfect, but effective. Decomposition started when the arrival of M. Gorbachev announced his proteges themselves and scientists, and skilled production workers, and the prophets, losing critical capacity. euphoria muddied mind. Dialectics in the management gave way to a desire to find an existing example that gave rise to rebirth of dialectical thought, 


\begin{tabular}{|c|c|c|c|c|c|c|}
\hline \multirow{4}{*}{ Impact Factor: } & ISRA (India) & $=3.117$ & SIS (USA) & $=0.912$ & ICV (Poland) & $=6.630$ \\
\hline & ISI (Dubai, UAI & $=0.829$ & РИНЦ (Russia & $=0.156$ & PIF (India) & $=1.940$ \\
\hline & GIF (Australia) & $=0.564$ & ESJI (KZ) & $=8.716$ & IBI (India) & $=4.260$ \\
\hline & JIF & $=1.500$ & SJIF (Morocco & $=5.667$ & OAJI (USA) & $=0.350$ \\
\hline
\end{tabular}

built on the basis of historical specificity of true knowledge, in primitive eclecticism Gaidar and $\mathrm{K}^{\circ}$.

To the natural desire to A. Aganbegian with associates to combine scientific knowledge economy with common sense and practical experience verified, washed liberal abstract fantasy.

In poor organization of the transition period to the modern high-tech economy, burdened by recession on a global scale and Western sanctions policy toward Russia is hardly realistic to count on the professional liability of a particular manufacturer for high-quality products. Morality was born before commercial production, but then economic development has put morality under its control, securing the new relationship ideologically. Moral development only in the novels is controlled internally characters. The economy morality exists like a jewel in a vice clamp ring. Why ISO standards focuses on three points of application of force - responsibility of the head, reducing costs and personnel policy? There are three "golden truth" quality policy in quality management:

$\square$ ignorance - the root cause of all the troubles in the management of the economy in the first place;

$\square$ quality - a source of income, as associated with the reduction of production losses, in addition, it ensures economic stability, improves the image;

$\square$ gentle policy towards professionally trained personnel, these people - the main wealth of any production.

\section{Conclusion.}

Rules apply when there is no reason not to comply with them - a more expensive each violation. We have, in terms of selective control over the rules, follow the rules of the rare manufacturers, a significantly greater effect on the concepts, that is, under the guise of imperfection rules and arrangements with officials. And here we can formulate the essence of the political moment, as leaders liked to say not very long ago. So, what do we have?

The first, quite by chance economics uncoupled from politics, political economy was neutralized in economics. God - gods, Caesar - Caesar's. Very much like the oligarchs and Gaidar American economic liberalism, and they repelled him specifically. Free enterprise took "a great success", and the Americans with draconian measures for violation of the rules of economic activity have forgotten to tell people. It was not profitable. Remember were only after all shared, and the question arose about the privatization redistribution of products.

In an effort to clean up the economic theory of the political meaning was hidden practice, management component. Economic Management separated from the subject specifics of production that was both theoretical mechanics, physics and chemistry. The next step for the abolition of the political economy and the priority in managing the production of its thematic orientation was the ascension of economic governance as a universal factor. Economic managers have become legislators order to develop production. In Russia in the 1990s, come in large numbers many economic advisers and consultants, intensified perhaps the most important financial speculator Soros. The question is, why all this had to be and who benefits? The answer is not so difficult - these changes have provided cover the transition from the production of quality management policies to manipulate the quality policy. The quality parameters were to determine the economic control naturally based management interests. Marx called the attempt is indicative of Proudhon economist to understand the philosophical foundations of Poverty "Poverty of Philosophy". Liberal economists have come to the same "economic" rake as their French predecessor. The result was the same. Removing substantive certainty, economists - managers restored scholastic philosophy "realists." Instead of moving to the concreteness of true knowledge they absolutised abstraction of general ideas. Economic science is intended to reconstruct the objective, subject certain reality, and not to be a producer convenient for calculating knowledge. Since the function of science and philosophy treated in the Middle Ages theologians. However, apparently, is in a similar status of science have a special interest, otherwise how to explain the departure from the objective criteria for scientific assessments, and listen to the advice of scientists - economists, to guarantee their businesses a stable financial position.

\section{References:}

1. Prokhorov, V. T., et al. (2017). The concept of import substitution products of light industry: prerequisites, objectives, innovation. monograph / under the total. Ed. Dr. tehn. Sciences, prof. VT Prokhorov (Eds.). Institute of Entrepreneurship and Service sector (branch) of the Don State Technical universiteta. (p.334). Novocherkassk: Leake.

2. Prohorov, V. T., et al. (2014). Quality Revolution: quality through advertising or through real quality: monograph under the total. 


\begin{tabular}{|c|c|c|c|c|c|c|}
\hline \multirow{4}{*}{ Impact Factor: } & ISRA (India) & $=3.117$ & SIS (USA) & $=0.912$ & ICV (Poland) & $=6.630$ \\
\hline & ISI (Dubai, UAE & $=0.829$ & РИНЦ (Russia & $=0.156$ & PIF (India) & $=1.940$ \\
\hline & GIF (Australia) & $=0.564$ & ESJI (KZ) & $=8.716$ & IBI (India) & $=4.260$ \\
\hline & JIF & $=1.500$ & SJIF (Morocce & $=5.667$ & OAJI (USA) & $=0.350$ \\
\hline
\end{tabular}

Ed. prof. VT Prokhorov (Eds.). ISOiP (branch) DSTU. (384). Novocherkassk: YURGPU (NPI).

3. Reva, D. V., Korablina, S. Y., Prokhorov, V. T., Narozhnaya, I. G., \& Tikhonov, N. (2016). Formation of import-replacing shoe assortment for domestic markets. II International scientificpractical conference "Models of innovative development of the textile and light industry on the basis of the integration of university science and industry. Education-Science-Production ": a collection of articles. March 23-25,.; M of the image. and Science of Russia, Kazan. nat. issled. tehnol. Univ. (pp.364-371). Kazan: Publishing house KNRTU.

4. Reva, D. V., Kovalev, K. G., \& Prokhorov, V. T. (2015). Innovative footwear technology for consumers and regions of the Southern Federal District North Caucasus Federal District. New in engineering and technology in the textile and clothing industry: Proceedings of the International scientific and technical conference. (pp.352-353). Vitebsk, Belarus: EE "VSTU".

5. Reva, D. V., Davtyan, G. G., Korablina, S. Y., Prokhorov, V. T., Aspen, T. M., \& Tikhonov, N. V. (2016). Creating conditions for import substitution of shoes in the Southern Federal District and the North Caucasian Federal District. Leather and fur in the XXI century: technology, quality, ecology, education: proceedings of the XII International Academico conference. (pp.320-327). Ulan-Ude: Publ VSGUTU.
6. Reva, D. V., Shrayfel, I. S., Mal'tsev, I. M., Prokhorov, V. T., Aspen, T. M., \& Volkov, G. Y. (2015). capabilities of software to assess the competence of professionals involved in the customs office as light industry experts. Proceedings of the higher educational institutions. North-Caucasian region. Series: Technical sciences, № 1 (182), pp. 42-53.

7. (2018). Quality management through motivation of behavior of light industry enterprise team leader. Monograph / under total. Ed. Dr. tehn. Sciences, prof. VT Prokhorov (Eds.). Institute of Entrepreneurship and Service sector (branch), Don State Technical University. (p.336). Novocherkassk: Leake.

8. Golovko, A. V., et al. (2019). On the possibilities of regulatory documents developed by the Quality Management System (QMS) for the digital production of defect-free importsubstituting products. Monograph / under the total. Ed. Dr. those. Sciences, prof. VT Prokhorov (Eds.). Institute of Entrepreneurship and Service sector (branch), Don State Technical University. (p.227). Novocherkassk: Leake.

9. Golovko, A. V., et al. (2019). Quality Management System - the basis for the production of technical regulation import-substituting products. monograph / under the total. Ed. Dr. tehn. Sciences, prof. VT Prokhorov (Eds.). Institute of Entrepreneurship and Service sector (branch), Don State Technical University. (p.326). Novocherkassk: YURGPU (NPI). 